\title{
Differentiation of subglacial conditions on soft and hard bed settings and implications for ice sheet dynamics: a case study from north-central Poland
}

\author{
Robert J. Sokołowski ${ }^{1}$ (D) Wojciech Wysota ${ }^{2}$
}

Received: 6 June 2019 / Accepted: 10 August 2020 / Published online: 11 September 2020

(c) The Author(s) 2020

\begin{abstract}
We reconstruct patterns of subglacial processes on a hard bedrock and a soft bed under the southern sector of Scandinavian Ice Sheet (SIS) occurring in the basal till of the Late Saalian Glaciation at the Wapienno, Barcin and Młodocin sites (northcentral Poland). Based on detailed sedimentological studies, two phases of SIS transgression were recognised. In the initial phase of the transgression, the SIS advanced onto a frozen substrate (continuous permafrost). The low permeability of the substratum led to a high subglacial water pressure (SWP) and increased basal sliding. The local increase of SWP led to the development of different types of structures and sediments. On a hard bedrock, with low SWP, abrasion predominated and linear structures were developing, while in the case of high SWP, the ice was decoupled from the hard substrate, pressurised liquefied sediment flowed, and structures of the p-form and s-form type developed. On a soft bed, the ice-bed contact was of a mosaic type and the ice movement had an ice-stream character. The ice-stream developed towards the east in the marginal zone of the SIS and used a W-E oriented valley filled by the Wapienno Formation fluvial complex. During a later phase, the ice movement was slower and did not have a stream character. Its direction changed to SE. The deposition of the main part of the diamicton occurred mainly as a result of the lodgement process.
\end{abstract}

Keywords Abrasional forms $\cdot$ Boulder pavement $\cdot$ Basal till $\cdot$ Palaeo-ice stream $\cdot$ Late saalian glaciation

\section{Introduction}

The dynamics of ice movement depends both on the amount and pressure of water in the subglacial zone and on the lithology and rheological properties of the substrate (Fischer et al. 1999; Piotrowski 2006; Harper et al. 2007; Benn and Evans 2010; Ravier and Buoncristiani 2018; Hart et al. 2019). The presence of permafrost in the forefield of an advancing ice sheet, or in its submarginal zone, can have an impact on the speed of ice flow and its stream character due

Robert J. Sokołowski

robert.sokolowski@ug.edu.pl

Wojciech Wysota

wysota@umk.pl

1 Department of Geophysics, Institute of Oceanography, University of Gdańsk, Al. Piłsudskiego 46, 81-378 Gdynia, Poland

2 Department of Geology and Hydrogeology, Faculty of Earth Sciences and Geospatial Management, Nicolaus Copernicus University, Lwowska 1, 87-100 Toruń, Poland to a decreased effective drainage of water into the substrate (Waller et al. 2012; Narloch et al. 2013).

The dynamics and directions of ice movement can be identified based on various types of erosion and deformation structures and landforms (van der Wateren et al. 2000; Stokes and Clark 2001; Glasser and Bennett 2004; Przybylski 2008; Lesemann et al. 2010). A faster ice flow, is inferred from geological evidence such as drag folds, shear structures, boulder pavements and ploughing structures (Piotrowski et al. 2001; Clerc et al. 2012). The occurrence of mega-scale glacial lineations is an important diagnostic for the identification of the zones of palaeo-ice streams (Stokes and Clark 2002; O'Cofaigh et al. 2013). Unfortunately, this applies only to areas affected by the Last Glaciation, where the land relief has not been obliterated by subsequent morphogenetic processes (Stokes and Clark 1999; Spagnolo et al. 2014).

The temporal and spatial variability of conditions in the subglacial zone is described by three main theoretical models. The first model suggests that an ice sheet overriding unconsolidated sediments may pervasively deform 
sediments due to the viscous rheology of a soft bed (Boulton 1986; Boulton and Hindmarsh 1987; Benn and Evans 2010). The second one is a ploughing model (Tulaczyk et al. 2001), where ice-bed irregularity (ice keels) cause the entrainment and transport of unconsolidated sediments according to the Coulomb-plastic rheology of till. And the third one is a model of a mosaic of deforming and stable spots based on the Coulomb-plastic behaviour of unconsolidated sediments below an ice-sheet (Iverson et al. 1998; Piotrowski et al. 2004). The mosaic model assumes changes in space and time of the pressure of subglacial water; increased water pressure at the base of an ice sheet causes its decoupling from its bed and intensification of basal sliding, whereas a decrease in water pressure results in the coupling of the ice with the bed and deformation of soft sediments. Models explaining subglacial processes are particularly important for the understanding of the role of ice streams in the functioning of ice sheets, including the Scandinavian Ice Sheet (SIS; Wysota et al. 2009; Gehrmann and Harding 2018).

Specific facies and/or structures develop on a hard and a soft substrate (Glasser and Bennett 2004; Evans 2007; Rea 2007; Benn and Evans 2010). Considering the geological characteristics of the areas under the influence of continental glaciation in the Pleistocene, traces of former subglacial processes on both substrate types can be rarely observed side by side. In particular, this refers to the Central European Lowland which remained on the edge of the SIS a couple of times during the Pleistocene (Ehlers and Gibbard 2004; Marks 2004; Svendsen et al. 2004). The aforementioned area is characterised by a significant thickness of non-lithified Cenozoic sediments which were subjected to subglacial processes (Różycki 1980; Eissmann 2002; Lindner et al. 2006). Outcroppings of the hard substrate, mainly Mesozoic, occur only locally, e.g., in the vicinity of Berlin, Germany (Rüdersdorf; Schulz 1967; Cepek 1995). In the Polish part of the Central European Lowland, only two such sites have been identified, i.e., Wapienno near Inowrocław and Czarnogłowy near Kamień Pomorski, the latter not investigated yet (NW Poland (Fig. 1).

Over 100 years ago, Wahnschaffe $(1893,1909)$ started to study subglacial erosion forms and structures at Wapienno. He was inspired by the observations of glacial striae on the Middle Triassic limestone at the well-known site of Rüdersdorf (Torell 1875). At the unique site in the Polish Lowland at Wapienno, Wahnschaffe $(1893,1909)$ conducted measurements of glacial striae in both the Upper Jurassic limestone and boulders of basal till covering the limestone layer. His investigations led to the conclusion that the orientation of glacial striae corresponded to the WNW-ESE direction. The abrasion traces on the hard substrate surfaces
Fig. 1 Study area and location of sites with respect to the Last Glacial Maximum and Late Saalian ice-sheet limit in northcentral Poland. $B$ Barcin site; $M$ Młodocin site

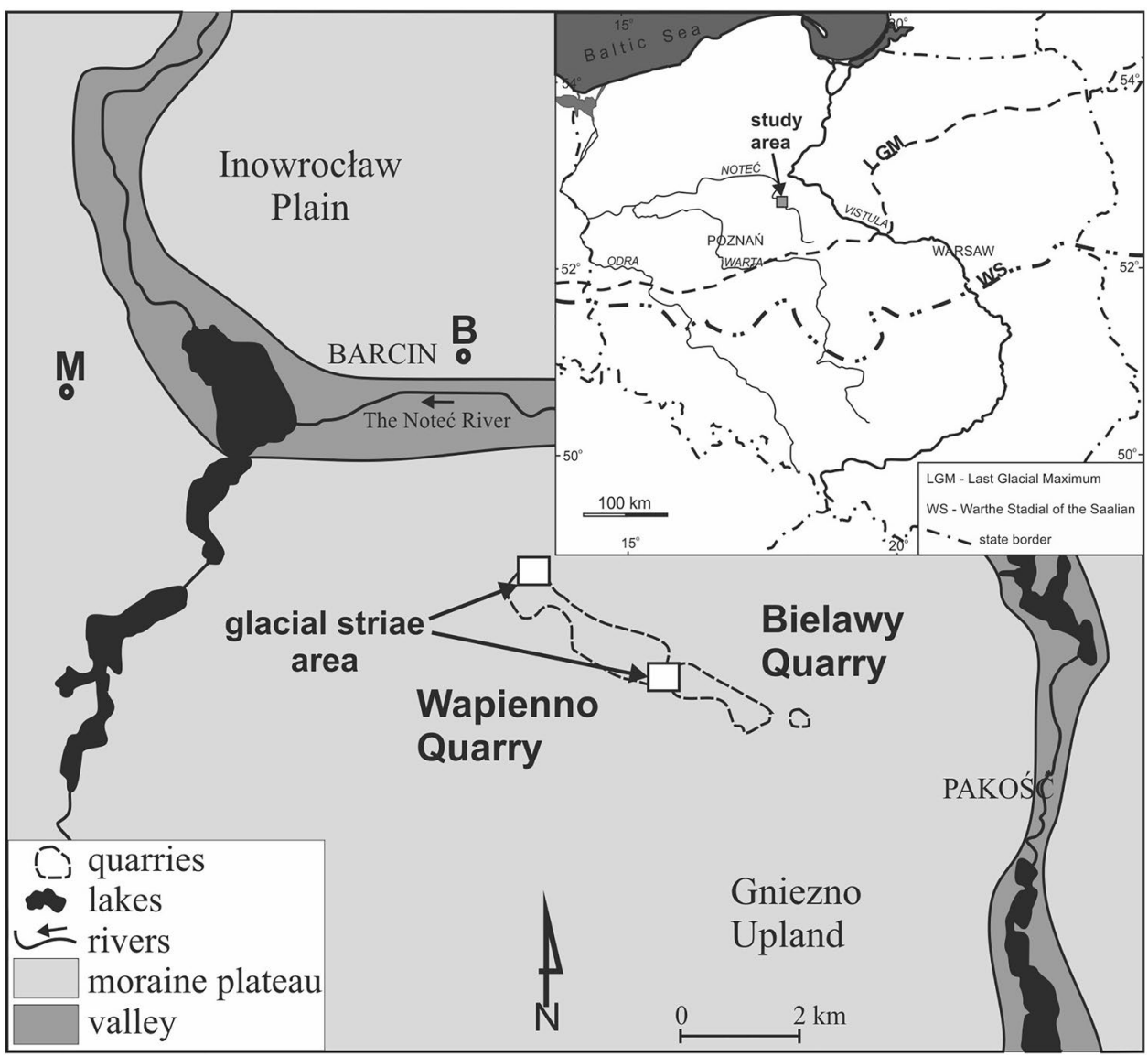


are still well visible at this site. The systematic uncovering of these surfaces during the removal of the overlying Pleistocene sediments resting on the Oxford limestone made it possible to investigate them in detail (Sokołowski 2007). Moreover, studies were conducted on the concurrent subglacial erosion and deformation processes on the soft bed at the aforementioned site as well as at the neighbouring Barcin and Młodocin sites (Fig. 1).

This paper examines a sequence of a deformed soft bed, abraded bedrock and glacial till deposited beneath the SIS during the late phase of Marine Isotope Stage 6 (MIS 6). An analysis of the literature and the results of investigations at the Wapienno, Barcin and Młodocin sites enabled the formulation of four research problems: (1) Which processes developed at the contact of the ice-sheet with the soft and hard substrate? (2) What was the role of water in subglacial processes? (3) What is the importance of the local ice-sheet movement direction in comparison with the southern sector of Scandinavian Ice Sheet (SIS)? (iv) Was the ice movement of the ice-stream type? Based on a detailed analysis, a reconstruction of the subglacial processes and ice sheet dynamics in the investigated area during this glaciation has been attempted.

\section{Regional setting}

The investigated area is located in north-central Poland at the edge of Gniezno Lakeland and Inowrocław Lowland (Kondracki 1998), both geographical regions being divided by the middle Noteć river valley (Fig. 1). It is situated ca. $70 \mathrm{~km}$ north of the maximum range of the Last Scandinavian ice sheet in the Late Weichselian (LGM), and ca. $150 \mathrm{~km}$ north of the range of the Late Saalian Glaciation (Wysota et al. 2009; Marks et al. 2018). The investigated sites are located within a moraine upland formed of glacial till, at
100-110 m a.s.1. Mesozoic rocks characteristic of the tectonic structure of Zalesie occur at a relatively high elevation (up to $103 \mathrm{~m}$ a.s.l.) in the substrate consisting of Pleistocene formations (Dembowska 1957). Zalesie is part of the Pomeranian section of the Mid-Polish Ridge (Dadlez et al. 1995). It formed as a result of the uplifting of the Upper Permian salts from the substrate consisting of Mesozoic sediments. The Mesozoic rocks, i.e., Upper Jurassic limestone and marl, have been uncovered in the"Wapienno" and"Bielawy" quarries. They are directly overlain by Pleistocene formations from 3 to over $30 \mathrm{~m}$ thick.

Two lithostratigraphic units, namely the Wapienno Formation and the Barcin Formation, have been identified within the uncovered Pleistocene sediments at the investigated sites (Sokołowski 2004; Wysota et al. 2009; Fig. 2). The Wapienno Formation, situated at a lower level, consists of sand facies with interlayered gravel and clay-silt of fluvial origin. Gravels and sands were deposited in the channel zone of the sand-bed braided river system, while fine-grained facies were deposited in overbank area. These sediments formed during the Lower and Middle Saalian Glaciation (Sokołowski 2007; Wysota et al. 2009). At the Wapienno site, they directly overlie the Upper Jurassic limestone (Fig. 2), while at the other two sites, they rest on the Pleistocene sediments which are older.

In Wapienno, the glaciogenic succession of the Barcin Formation is underlain by the Wapienno Formation deposits, and in some locations they directly cap the Upper Jurassic limestone. The Barcin Formation consists of five units including three glacial ones (till units), i.e., B1, B3 and B4 (Sokołowski 2007; Fig. 2).

Unit B1, which is the lowest, consists of till with a thickness of 1.5-5.5 m interpreted as the Warthe Stadial of the Saalian Glaciation (Sokołowski 2007; Wysota et al., 2009). At the interface between Unit B1 and the Upper Jurassic
Fig. 2 Synthetic profile of the Pleistocene and Upper Jurassic sediments in the Wapienno area Unit B1-late Saalian till; unit B2-middle and late Weichselian fluvial and fluvioglacial sands and gravels; unit B3-late Weichselian till (Leszno Phase); unit B4-late Weichselian till (Poznań Phase); unit B5-late Weichselian gravels and sands, not scaled

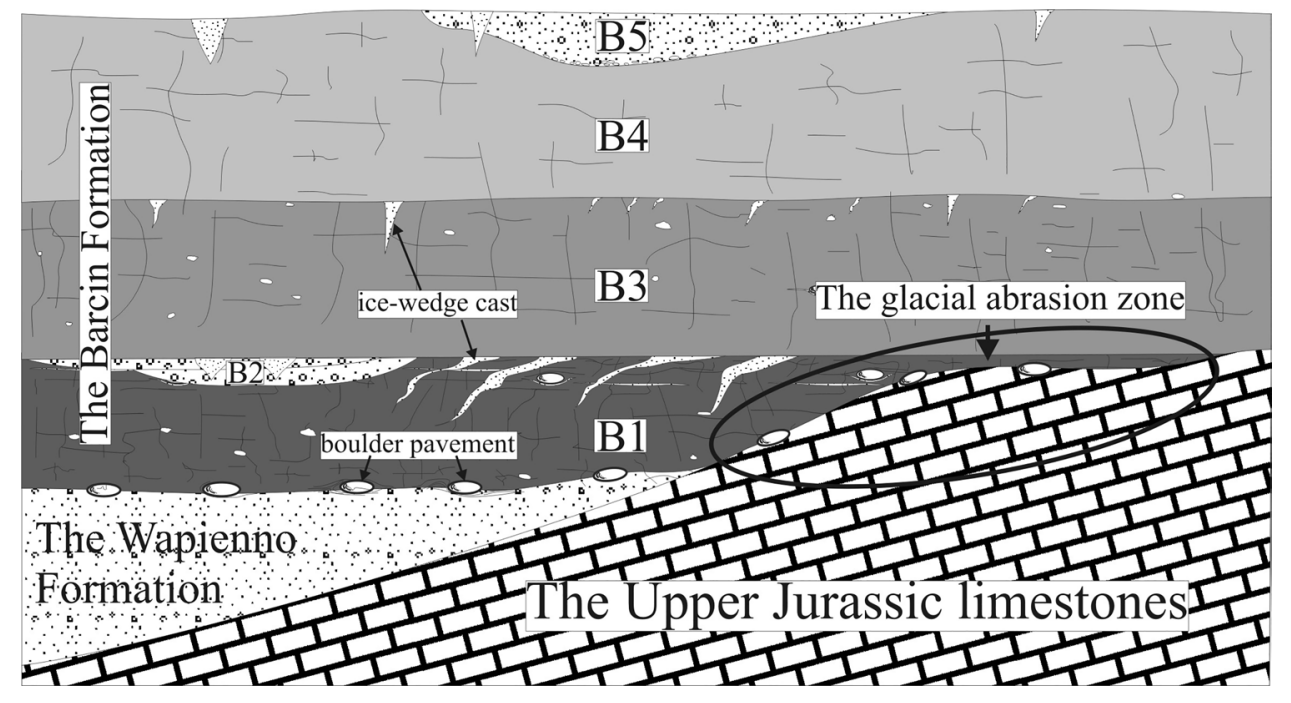


limestone, there are forms of glacial abrasion, while at the contact with the Wapienno Formation sediments, boulder pavement with ploughing marks commonly occurs, and locally, below the contact, deformation till facies and glaciotectonites were documented.

\section{Methods}

The presented results are based on the detailed field studies conducted in the SE area of the Wapienno quarry bordering with the Bielawy quarry, and at the sites in Barcin and Młodocin (Fig. 1).

Abrasional structures on a hard substrate were analysed in the SE part of the Wapienno quarry at four sites, each having from 8 to $15 \mathrm{~m}^{2}$ of surface area (Fig. 3). The sites were thoroughly cleared of the basal till overburden, and later analysed in detail. The studies mainly dealt with microscale morphology features such as striae, crescentic gouges and fractures, micro crag and tails, small stoss-lee forms, grooves and s-forms. The length, height, depth and orientation of these structures were determined.

Structures on a soft bed were investigated at all three study locations. Most boulders within the boulder pavement area were analysed with respect to their size, distance between the boulders, and the type, orientation and sequence of deformational forms. Standard sedimentary analyses (texture, sedimentary structures, bed thickness, nature of bed contacts, etc.), were performed in several profiles and along exposures. Within B1 till, the orientation and plunge of pebble-sized clast axes were measured. Only clasts with $a: b$ axis ratios between 2:1 and 3:1 were measured. Abrasional forms, i.e., striae and small crescentic gouges, were measured on the surface of the embedded boulders, till-fabric above the boulder pavement and subglacial deformations that had developed below the pavement. The measurements of glacial striae on boulders and the limestone surfaces were analysed and later plotted as contour diagrams using StereoNet 3.0 software. The mean lineation vector (MLV) of clast orientation and its strength (S1) were calculated by applying eigenvector analysis (Davis 1973).

\section{Results}

\section{Abrasional forms on a hard bed}

Micro-scale forms, classified after Bennett and Glasser (2011), dominated among the abrasional features. The whole potential area covered with abrasional forms resting on limestone probably ranged from a couple to several thousand $\mathrm{m}^{2}$. This is most likely due to the tectonic conditions, because limestone outcroppings are cut by the numerous strike-slip faults. The other contributing factor is the lithology of the Mesozoic rocks. Abrasional forms could only develop and remain at sites, where the ice sheet had abraded the massive, unweathered pelitic Oxford limestone.

The dominant abrasional forms were glacial polish and striae (Table 1). The measurements of linear forms, particularly Type 3 glacial striae and micro crag and tails (Table 1 ), indicated that the ice masses were flowing in the eastern direction (Fig. 4a, c). The analysis of linear measurements
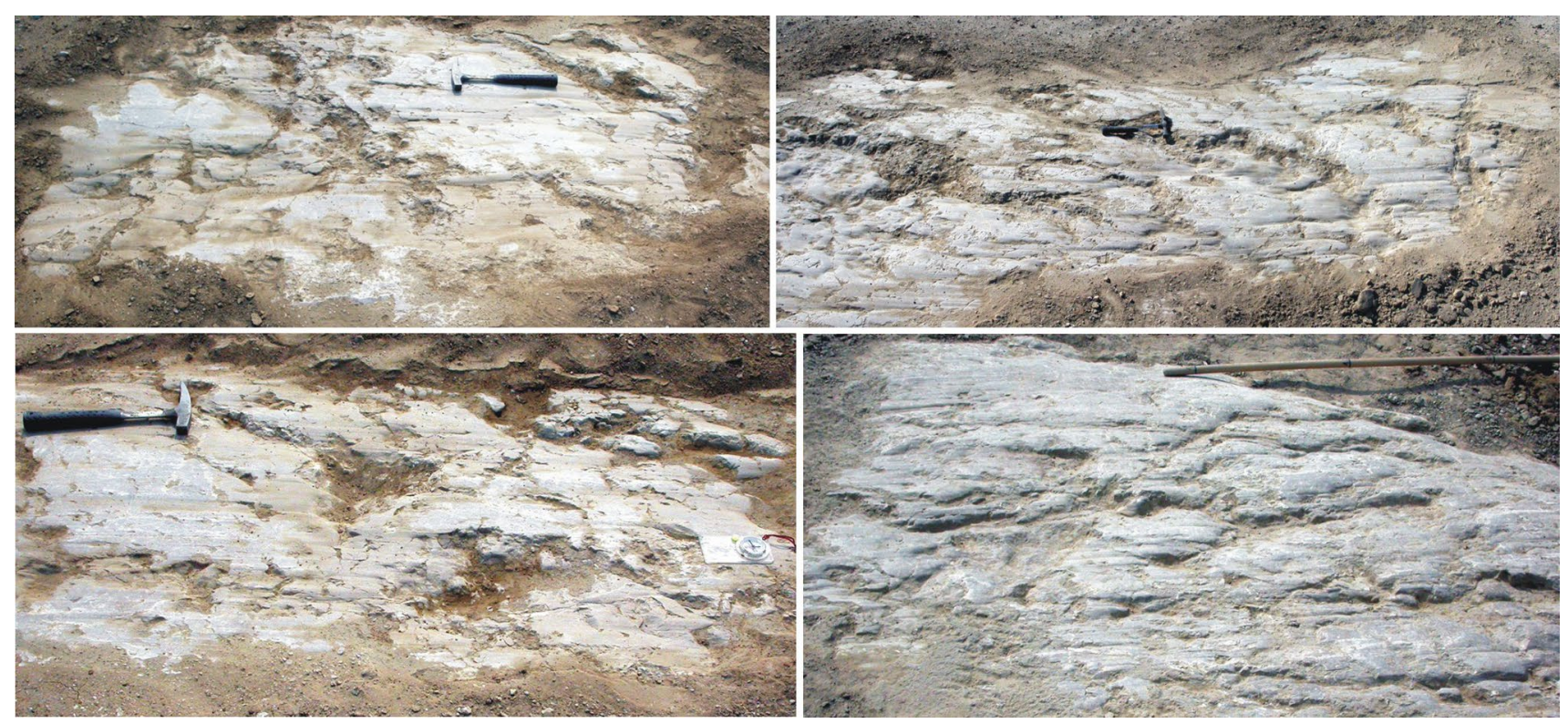

Fig. 3 View of the four test fields with abrasive structures in the Eastern Wapienno quarry. Ice movement direction from right to left side 
Table 1 Description of abrasive forms

\begin{tabular}{|c|c|c|c|}
\hline Type of form & Size & Process & Frequency \\
\hline Glacial polish & & $\begin{array}{l}\text { Polishing of hard bedrock by the finest material }(\leq 0.01 \mathrm{~m}) \\
\text { highly saturated with water }\end{array}$ & Common \\
\hline $\begin{array}{l}\text { Striae (mainly type } 3 \text { and } 2 \text { by Iverson } \\
\text { 1991); (Fig. 4a, b) }\end{array}$ & $\begin{array}{l}\text { Length: } 0.05-1 \mathrm{~m} \\
\text { Depth: } 0.01-0.03 \mathrm{~m}\end{array}$ & $\begin{array}{l}\text { Abrasion of the bedrock by rock fragments }(\geq 0.01 \mathrm{~m}) \\
\text { embedded at the floor of an active, sliding glacier }\end{array}$ & Common \\
\hline Micro crag and tails (Fig. 4c, d) & $\begin{array}{l}\text { Length: } 0.03-0.15 \mathrm{~m} \\
\text { Width: } 0.01-0.02 \mathrm{~m}\end{array}$ & $\begin{array}{l}\text { Small tails of bedrock not affected by glacial abrasion on } \\
\text { the lee side of resistant grains or mineral crystals }\end{array}$ & Relatively rare \\
\hline Bedrock gouges and cracks (Fig. 4e, f) & $\begin{array}{l}\text { Width: } 0.04-0.14 \mathrm{~m} \\
\text { Depth: } 0.01-0.05 \mathrm{~m}\end{array}$ & $\begin{array}{l}\text { Bedrock fracturing as a result of point contact pressure of } \\
\text { rock debris at the base of the ice sheet }\end{array}$ & Relatively common \\
\hline Small stoss and lee forms (Fig. 5a, b) & $\begin{array}{l}\text { Length: } 0.3-0.5 \mathrm{~m} \\
\text { Width: } 0.1-0.3 \mathrm{~m}\end{array}$ & $\begin{array}{l}\text { Abraded stoss side and quarried lee side under active ice. } \\
\text { The velocity of ice is high and the effective normal pres- } \\
\text { sure is low }\end{array}$ & Rare \\
\hline Sichelwannen; (Fig. 5c) & $\begin{array}{l}\text { Length: } 0.3-0.5 \mathrm{~m} \\
\text { Width: } 0.1-0.3 \mathrm{~m} \\
\text { Depth: } 0.03-0.06 \mathrm{~m}\end{array}$ & $\begin{array}{l}\text { Formation by subglacial meltwater and/or by abrasion of } \\
\text { slurry till in turbulent flow }\end{array}$ & Relatively common \\
\hline Sinuous grooves (Fig. 5d) & $\begin{array}{l}\text { Length: } 0.4-1.2 \mathrm{~m} \\
\text { Width: } 0.05-0.1 \mathrm{~m} \\
\text { Depth: } 0.02-0.05 \mathrm{~m}\end{array}$ & $\begin{array}{l}\text { Formation by subglacial meltwater and/or by abrasion of } \\
\text { slurry till in turbulent flow }\end{array}$ & Rare \\
\hline
\end{tabular}

yielded the azimuth of $110^{\circ}$ (Fig. 5). No other orientation of linear elements on the abraded surfaces was detected.

The presence of bedrock gouges and crack type forms was determined. Indentations with their horns pointing downglacier (crescentic fractures), with the arch width ranging from a couple to $15 \mathrm{~cm}$ and depth of $1-5 \mathrm{~cm}$, were a dominant feature (Table 1; Fig. 4e, f).

The other glacial abrasion forms were stoss and lee forms. They occurred relatively rarely and were $15-40 \mathrm{~cm}$ long and 5-10 cm high (Table 1; Fig. 6a, b). Their development was facilitated by the system of diagonal fractures in the limestone roof.

P-forms and s-forms were relatively common at all study sites. The presence of two types of these structures was determined. Sichelwannen were one of them. Their length ranged from 30 to $50 \mathrm{~cm}$, while the width and depth were 10-30 and 3-5 cm, respectively (Table 1; Fig. 6c). In general, the proximal side of sichelwannen was characterised by a semi-circular shape and slant edge typical of this form (Gray 1982; Shaw 1988; Bennett and Glasser 2011). The other form type were sinuous small grooves (Fig. 6d) which usually occurred together with sichelwannen. They were up to $1 \mathrm{~m}$ long, $10 \mathrm{~cm}$ wide and 2-3 cm deep (Table 1). Their appearance resembled curved flutes as described by Shaw (1988).

\section{Erosional and deformational structures on a soft bed}

At the interface between the Wapienno Formation sediments and the till of Unit B1, subglacial deformations occurred locally. The spatial distribution of zones with the developed deformations and the intercalating zones with a sharp erosional contact (no traces of deformation) were characterised by a mosaic pattern. The width of the deformation zones is $20-60 \mathrm{~m}$ and the depth is from about a dozen centimetres to $4-5 \mathrm{~m}$. Based on a detailed sedimentological investigation, three facies were distinguished within the deformation zones and the diamicton (Fig. 7). They differ with regard to the degree of deformation and presence of sediment inclusions in the Wapienno Formation.

\section{Facies A}

It encompasses the deformed sediments of the Wapienno Formation without an admixture of moraine material. Its thickness ranges from 1 to $5 \mathrm{~m}$. In the lower part, a system of normal dip-slip faults or, more rarely, strike-slip faults predominates (Fig. 8a, b). The distance of movements along the faults ranges from a few to about a dozen centimetres. The dip of the fault plane is towards W. The degree of sediment disturbance in the Wapienno Formation is small enough to enable the reading of primary sedimentary structures. The slope of the fault planes decreases upwards and gradually they transition into a horizontal secondary lamination (Fig. 8a). They are accompanied by various types of small folds, mainly recumbent and isoclinal (Fig. 8c, d).

\section{Facies B}

Two subfacies were distinguished within this faces: $\mathrm{B}_{1}$ and $B_{2}$. They probably form horizontal transitions in the zone of strong deformations and mixing of substrate sediments and moraine material.

Subfacies $\mathbf{B}_{1}$-it is formed by a very sandy, olive grey diamicton. The mean thickness of subfacies $B_{2}$ ranges from 

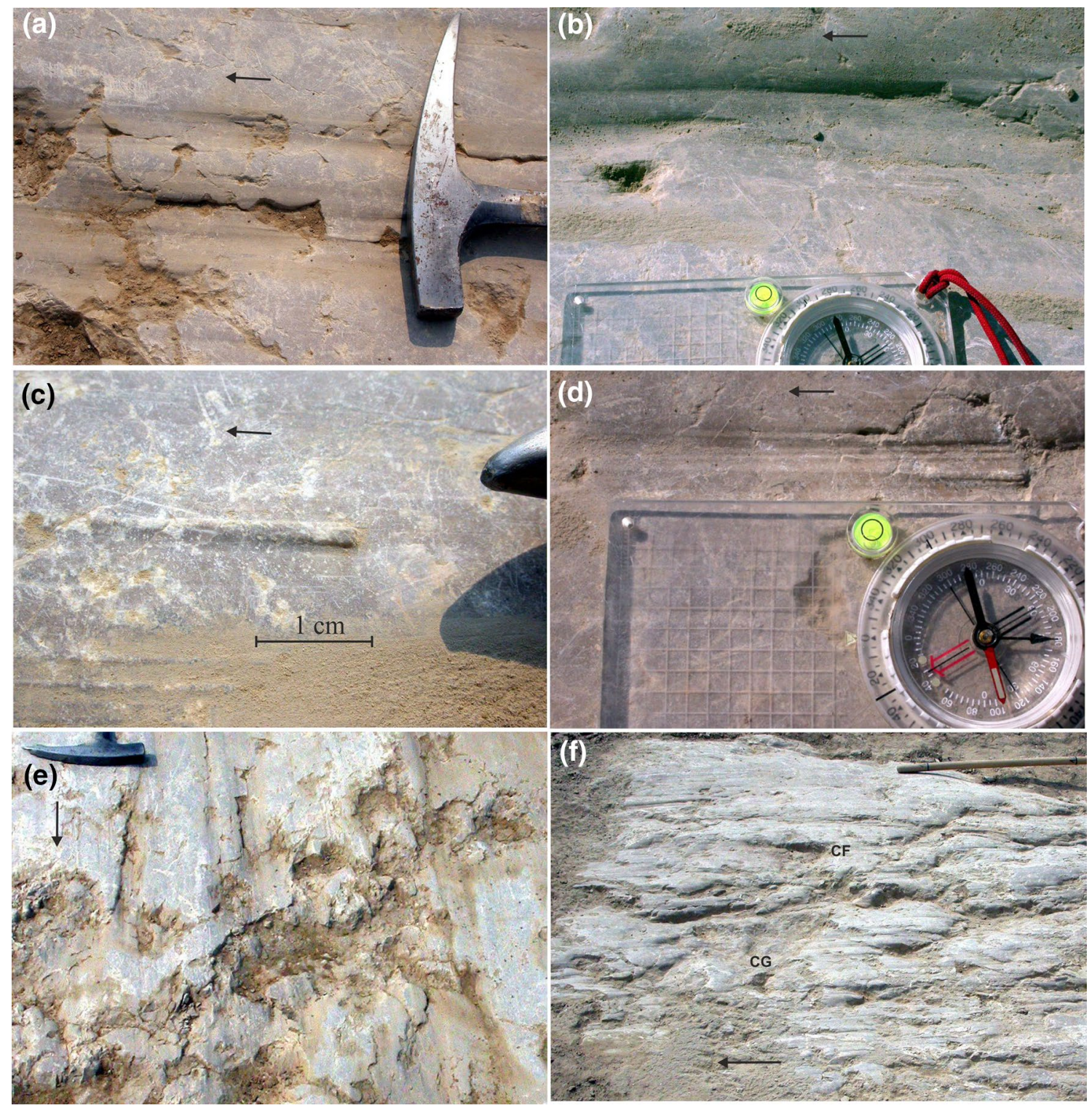

Fig. 4 Eastern Wapienno quarry. a, b Glacial striae type 3; c, d micro crag and tails; e, $\mathbf{f}$ crescentic fractures (CF) and gouges (CG). Black arrows show ice movement direction

0.5 to $1 \mathrm{~m}$. A characteristic feature of this subfacies are small lenses of light-grey sands within the moraine material (Fig. 8e). The moraine and sand material is so strongly mixed that the primary sedimentary structures are totally obliterated in both sediments. The sandy lenses are sometimes so scattered that they form a subhorizontal lamination (Fig. 8e). The lenses are between a dozen to $40-60 \mathrm{~m}$ long along the direction of the ice movement. In the cross-wise direction, their width is probably a dozen or so metres. Their thickness ranges from a few centimetres to nearly $1 \mathrm{~m}$.

Subfacies $\mathbf{B}_{2}$-its thickness ranges from 0.2 to $1.5 \mathrm{~m}$ (Fig. 9). It developed as a blend of layers of olive grey, massive diamicton and sandy sediment lenses of the Wapienno
Formation. The diamicton sometimes exhibits primary structural features such as the grey-green colour, massive structure, fractures emphasised by Fe compounds (Figs. 8g, 9d, e, f). It is usually strongly disturbed, forming boudins and scattered lenses within the sandy sediments. Between the disturbed fragments of diamicton layers, there is sandy material mixed with fine clayey clasts (Fig. 9f). The entire material is highly folded, mainly in the form of isoclinal, drag and asymmetrical folds (Fig. 9a). The structures of sandy sediments are obliterated, and the sediments themselves are highly folded. The degree of stretching of the folds is sometimes so high that form a secondary horizontal lamination in the sandy-diamicton material. The bottom and top boundary 


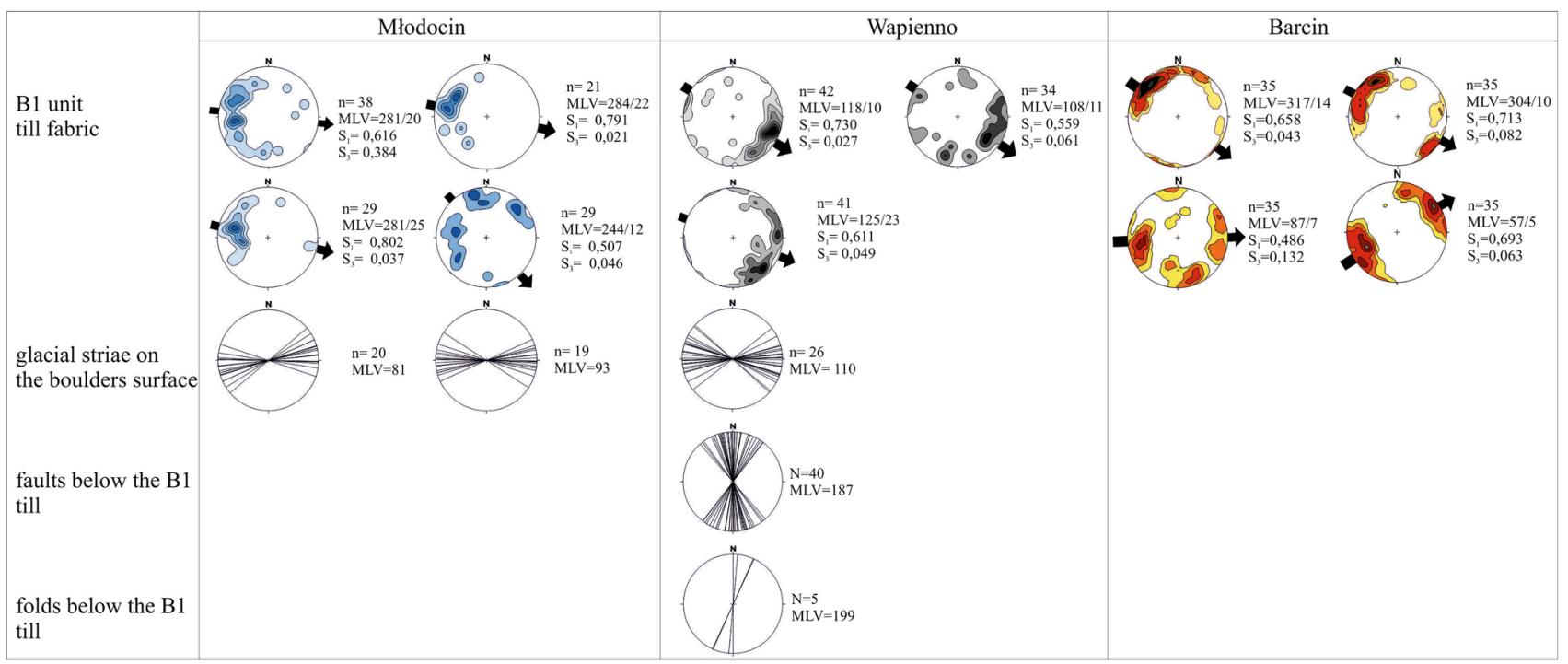

Fig. 5 Stereonet plots of till fabric within till units B1, glacial striae on the faceted surface of boulders, faults and folds below the B1 till in sites Młodocin, Wapienno and Barcin
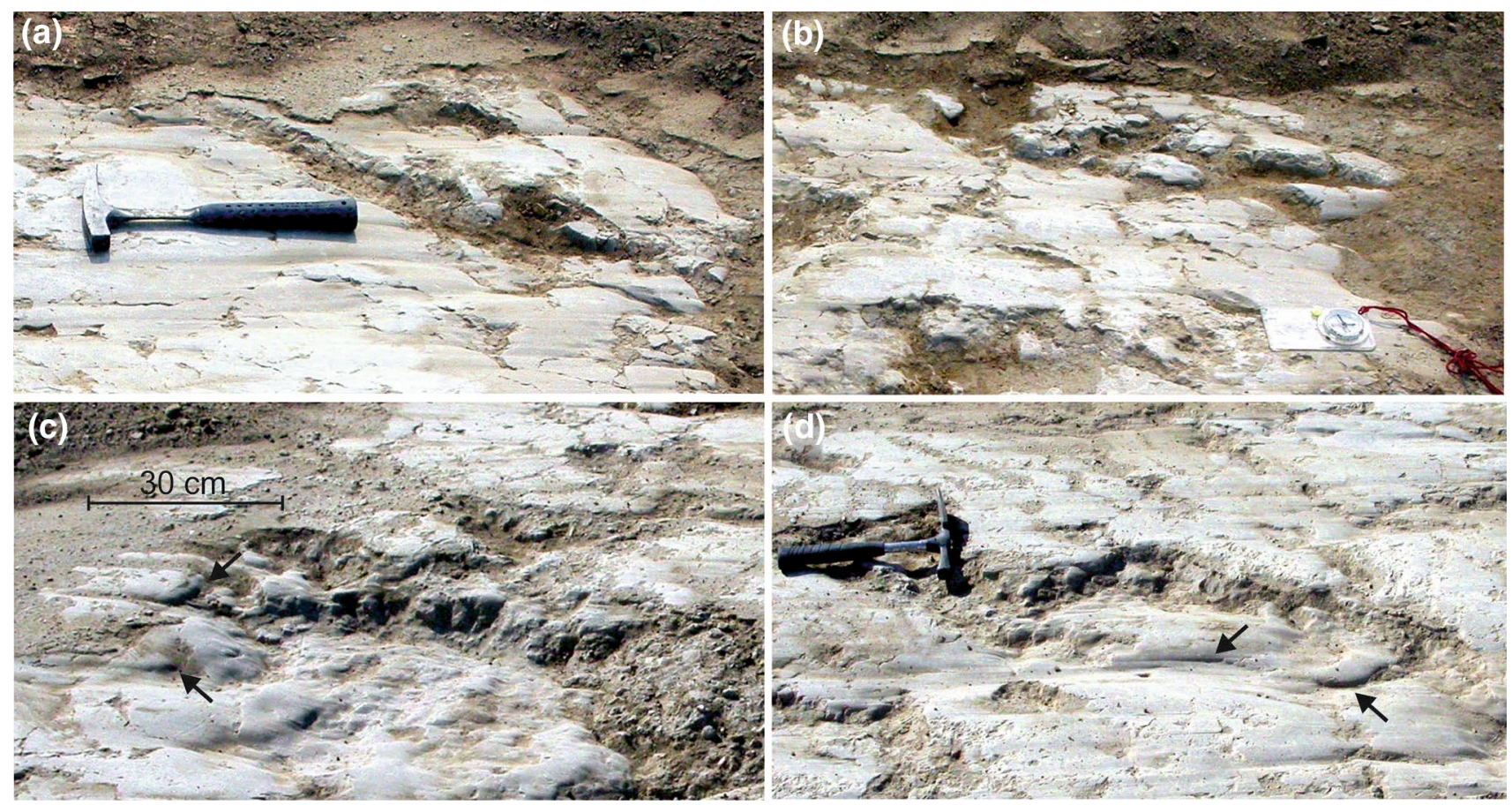

Fig. 6 a, b Small stoss and lee forms; c sichelwannen (black arrows); d sinuous small grooves (black arrows)

of this subfacies is transitional, rarely distinct. The horizontal sandy layers transition into subhorizontal lamination within the diamicton (Fig. 9d).

Within Facies B at the Wapienno and Barcin sites, clastic dykes occurred. They were absent in the zones of sharp, undisturbed till-bottom contact. The dykes were up to several meters long and $20-30 \mathrm{~cm}$ wide (Fig. 9a). They were filled with moraine material that displayed visible parallel lamination oriented in the same direction as the dykes (Fig. 9b). In bigger dykes, the infilling consisted of a different type of sediments (silty and sandy laminae). Smaller dykes were filled with more fine material (silt to clay) with clay aureoles around them (Fig. 9c). Smaller dykes were also partially parallel to the lamination in the host sediments. 

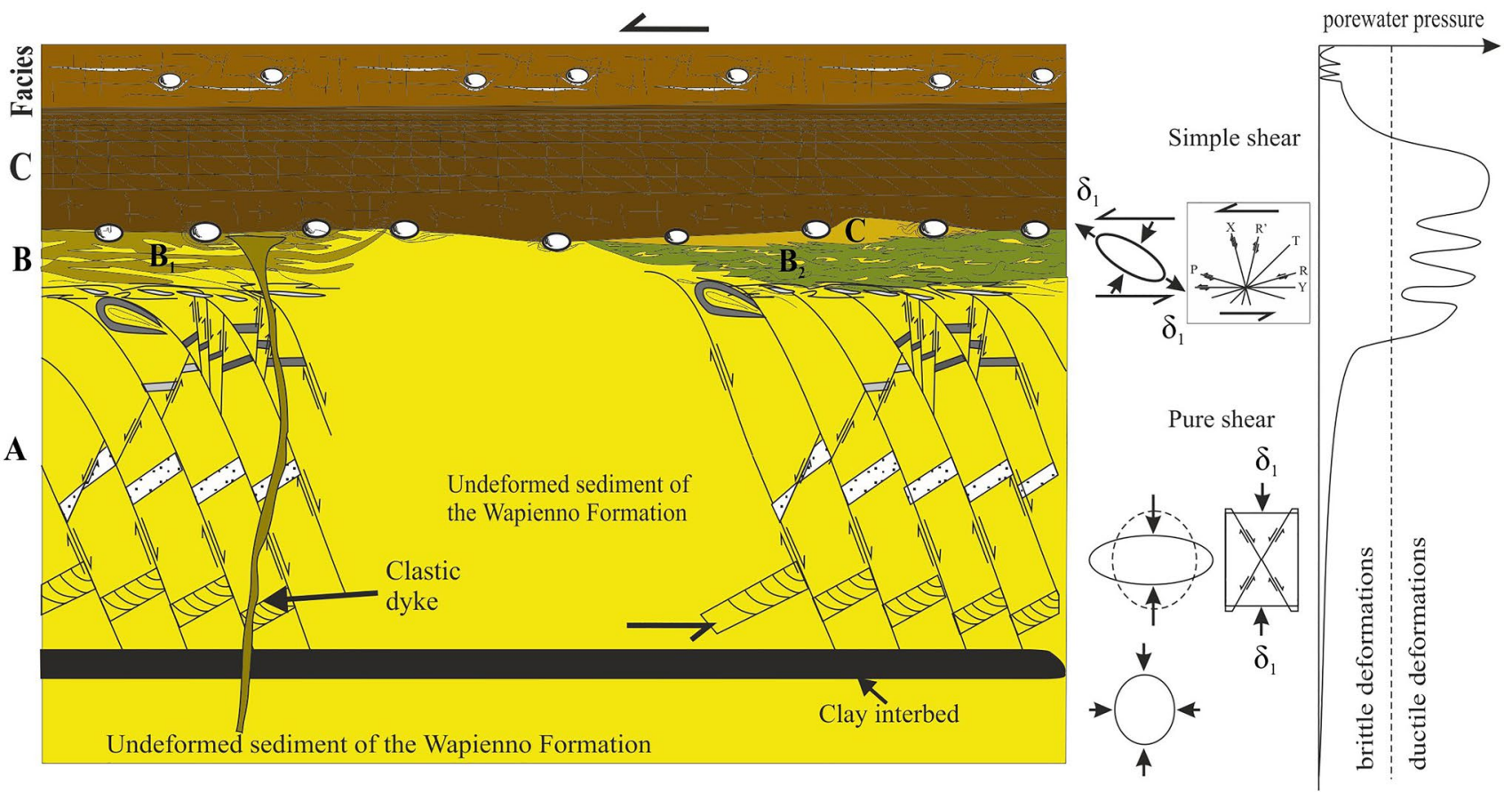

Fig. 7 Facies model, strain types and porewater pressure diagram

\section{Facies C}

It is formed by clay-rich brown diamicton, $30-40 \mathrm{~cm}$ thick, in the south-eastern part of the Wapienno site and 1.5-3.0 m thick in its western part and at the Młodocin site. In its bottom part, the diamicton has a massive structure. In its bottom and central part, there is a network of fractures whose density increases upwards (Fig. 9e). The fractures are emphasised by precipitates of $\mathrm{Fe}$ compounds. The size of the individual fracture cells ranges from $5-10 \mathrm{~cm}$ in the bottom part to do $0.5 \mathrm{~cm}$ in the top part. Subhorizontal fractures form the main pattern. The shape of the fractures is sometimes sigmoidal. Another direction is formed by fractures whose pattern is close to vertical. There are no traces of greater displacements along both directions of the fractures. It is emphasised by the presence of undeformed clasts of soft sediments in the fracture network (Fig. 10a). The bottom boundary is usually distinct or sharp. This facies constitutes the main part of unit B1. The clay-rich massive diamicton transitions upwards to dark brown sandy diamicton with a laminated structure. The laminae are made up of loamysandy material (Fig. 10b). The primary structure of this diamicton (particularly in the top part) is usually disturbed.

A layer of embedded boulders commonly occurred at the base of facies C of Unit B1 that rests on the Wapienno Formation sediments (Fig. 10d-i). The boulder pavement consisted of far-travelled crystalline rocks from Scandinavia which were mainly different types of granites and gneisses. The pavement was present at the interface between facies $\mathrm{C}$ and the disturbed sediment (Figs. 9a and 10c) bed as well as the non-disturbed sediments (Fig. 10h). It was built from boulders ranging in size from several centimetres to over $1 \mathrm{~m}$. The boulder-to-boulder distances varied from 0.5 to 4-8 m, and were proportional to boulder size (Fig. 10c, e, h). The upper surfaces of boulders with the diameters larger than $20 \mathrm{~cm}$ were visibly faceted. These surfaces displayed a singular pattern of striae and also patchy indentations in the shape of crescentic gouges with a characteristic arching bend (Fig. 10d). Among a few dozen of the measured boulders, only one displayed striae on its bottom part. The size and sharpness of fractures was proportional to the boulder size. In general, the boulders with a diameter of less than $20 \mathrm{~cm}$ did not have traces of abrasion on their upper surface.

The majority of boulders displayed ploughing marks and sediment prows (Fig. 10g-i). Ploughing marks were filled with poorly homogenised fine-grained diamicton, and sometimes with the disturbed sand substrate with an admixture of small amounts of moraine material. The depth of deformations that originated from the ploughing of boulders reached a maximum of 2.5-3 times of the clast diameter although, in general, it approximated the boulder diameter (Fig. 10g, h). Between boulders and along them, keels of diamicton are visible (Fig. 10h, i). The directions of their axes are parallel to glacial striae on the upper surfaces of the ploughing boulders. The height of the keels is from several $\mathrm{cm}$ up to $20 \mathrm{~cm}$.

In the eastern part of the Wapienno quarry, just below unit B1, erosional structures dissecting sand sediments of the Wapienno Formation were discovered (Fig. 10j). They 

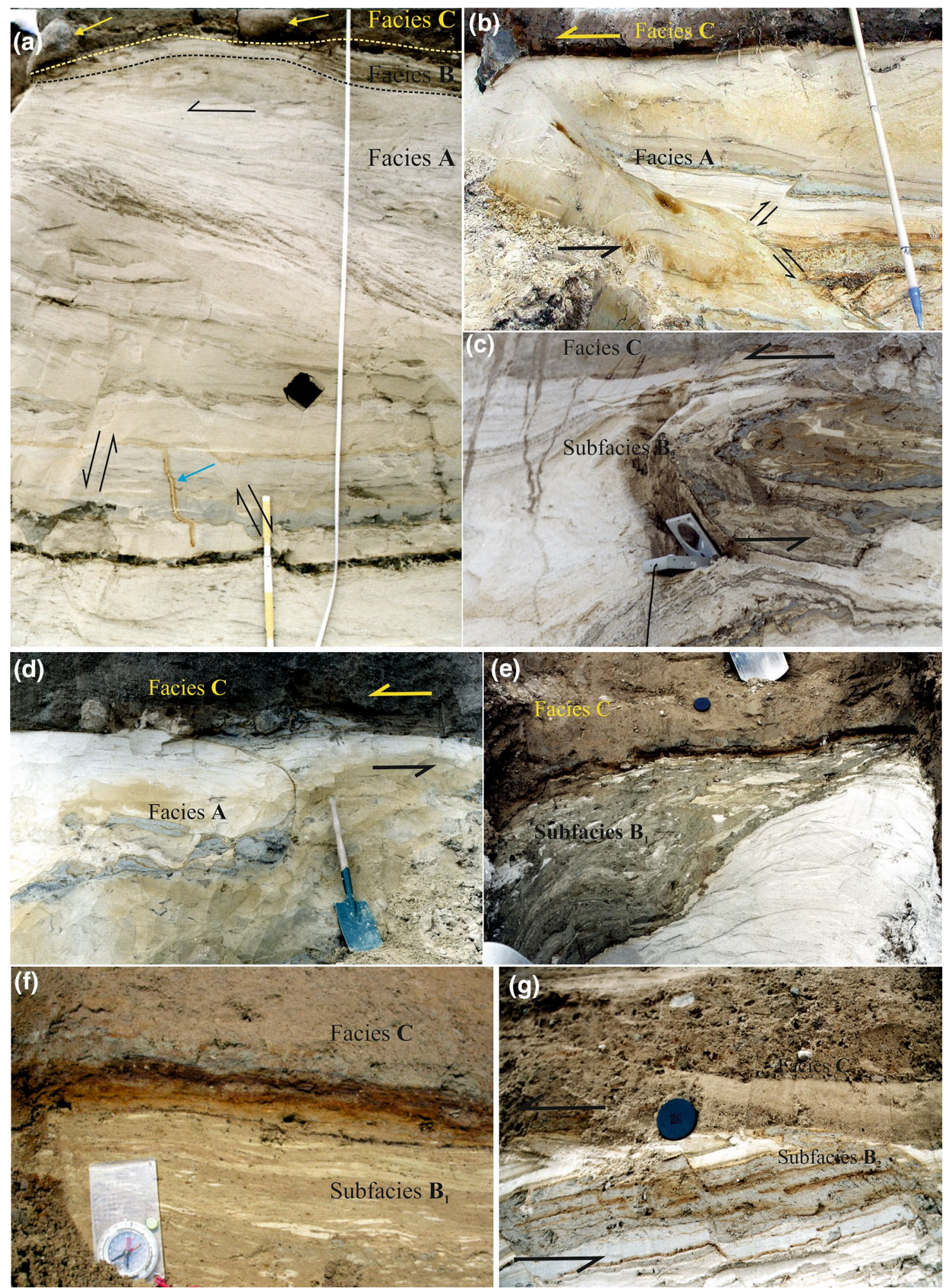

Fig. 8 Western part of the Wapienno site: a Contact of main B1 facies. Note boulder pavement at the bottom of facies $\mathrm{C}$ (yellow arrows) and small clastic dyke (blue arrow); $\mathbf{b}$ direct contact of facies $\mathrm{A}$ and $\mathrm{C}$ without deformations. Small thrust faults of facies $\mathrm{A}$ and ploughing clast in the left corner of photo; eastern part of the Wapienno site: $\mathbf{c}$ folded till in deformation zone (subfacies $\mathrm{B}_{2}$ ); $\mathbf{d}$ defor- mation contact between facies $\mathrm{A}$ and $\mathrm{C}$ with boulder pavement at the bottom of facies $\mathrm{C}$; western part of the Wapienno site: e ductile deformations (subfacies $B_{1}$ ) below facies $C$. Ice movement from the photo's site; $\mathbf{f}$ secondary lamination in subfacies $\mathrm{B}_{1}$, western part of the Wapienno site. Ice movement from the photo's site; $\mathbf{g}$ contact between facies $\mathrm{C}$ and subfacies $\mathrm{B}_{2}$, western part of the Wapienno site 


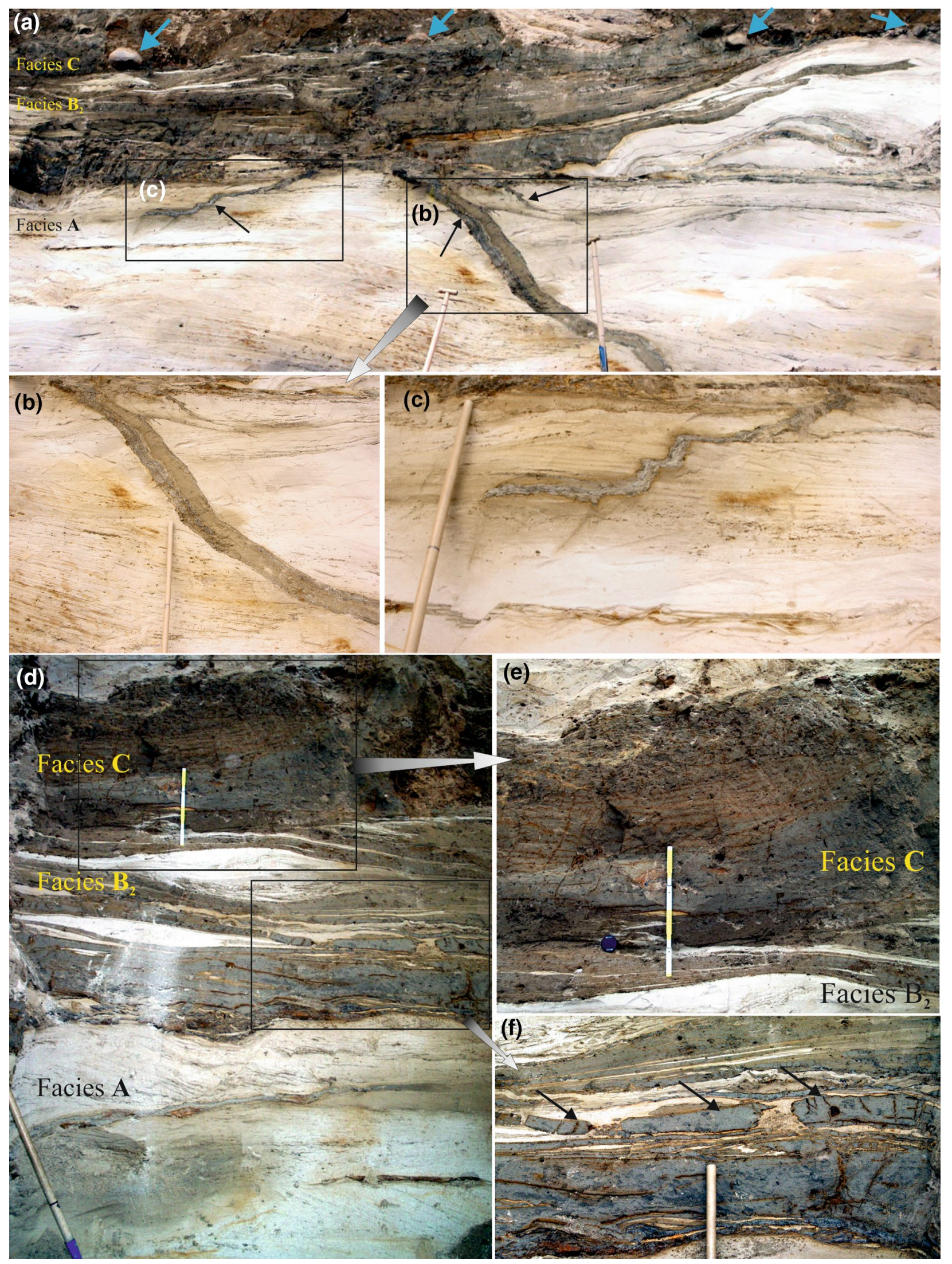


4Fig. 9 Eastern part of the Wapienno site. Ice movement from photo's site. a Overview on facies contact. Black arrows-clastic dykes, blue arrows-boulder pavement; b Internal structure of big clastic dyke. Notice fine laminae in outer part of dyke and sandy laminae inside; c small clastic dyke with clay aureole around; d deformed diamicton in subfacies $\mathrm{B}_{2}$. Notice subhorizontal clastic dykes in facies $\mathrm{A}$; $\mathbf{e}$ fining-upward shear fractures in overconsolidated diamicton of facies $\mathrm{C}$; $\mathbf{f}$ shear deformations and tectonic lamination of diamicton and the Wapienno Formation sands. Notice small water escape structures between disrupted diamicton clasts (black arrows)

formed vertical features up to $0.7 \mathrm{~m}$ deep and $1 \mathrm{~m}$ wide with a characteristic sharp contact with the surrounding sand sediments. The structures were infilled with homogeneous clay-rich diamicton of facies $\mathrm{C}$.

\section{Ice-movement directions}

Measurements of striae orientation on the surface of the faceted boulders were performed at the Wapienno and Młodocin sites. The longer axes of the analysed boulders were mainly sloping in the western direction (up-ice dip) at an angle of $6^{\circ}-12^{\circ}$. The mean vectors indicated the direction of $110^{\circ}$ at the Wapienno site, and $81^{\circ}$ and $93^{\circ}$ in Młodocin (Fig. 5). The measurements of the till fabric in the diamicton overlying the boulder pavement at all three study sites showed a unimodal distribution of directions, which was more or less in agreement with the orientation of the striae. The dominant direction was W-E in the lower part of the unit B1, transitioning to NW-SE in the upper part. The $\mathrm{S}_{1}$ eigenvalues from 0.48 in the Barcin site to 0.8 at the Młodocin site indicate a changeable clast arrangement in the lower part of unit B1. In the upper part of unit B1, the $S_{1}$ eigenvalues indicate moderate clast arrangement (0.56-0.73; Fig. 5).

Linear elements in the top part of the limestone, striae on the upper surfaces of the ploughing boulders and results of measurements of the till-fabric in the bottom part of unit B1 correspond to each other in all study sites. They indicate the local direction of basal ice movement in the initial transgression phase of the SIS that was flowing from the west to the east at that time (Fig. 5). The directions of folds and faults planes in facies A are perpendicular (N-S) to the direction established based on the other measurements. Such a pattern is a result of the stress system beneath the ice sheet (Van der Wateren et al. 2000; Roman 2019). The measurements of till-fabric from the upper part of facies $\mathrm{C}$ diverge from that as they indicate a change in the direction of ice movement from W to NW (Fig. 5).

\section{Interpretation}

The observation of long, continuous profiles of exposures enabled to find the alternating occurrence of zones of contact between Unit B1 till with the soft substrate, affected and not affected by deformation. This concerns both exposures oriented parallel and perpendicularly to the direction of the ice movement. It seems that such a division into zones was related to the spatial and temporal variability of subglacial conditions determined by changes in the pressure of subglacial water (cf. mosaic of deforming and stable spots model, Piotrowski et al. 2004) (Fig. 7). The obtained study results show that the main factor controlling the processes in the subglacial zones were changes in subglacial water pressure (SWP) at the ice-bed interface and, to a smaller degree, the pressure gradient in the substrate beneath the ice sheet. Two states were distinguished in the conducted investigations: low and high SWP. Low SWP is understood as a state, where the ice sheet clings to its substrate. High SWP is understood as a state, where the amount of water in sediments causes a decrease of intragranular friction, which enables their deformation and, within the ice sheet, approximates the boundary value enabling the decoupling of the bottom of the ice sheet from the substrate and its basal sliding without the deformation of the substratum (Iverson 2010; Minchew et al. 2016; Phillips et al. 2018).

\section{Low SWP}

In zones of effective drainage, the thin (several to a dozen or so centimetres) layer of sands in the Wapienno Formation was subjected to deformation (Facies B). The ice movement occurred then mainly by basal sliding (Thomason and Iverson 2008). Ploughing structures and keels of diamicton are a record of this process on a soft substrate (Fig. 10a-h). For low SWP to continue, the permafrost in the Wapienno Formation sediments must have disappeared, or must have been of the patchy type. On a hard substrate, the direct contact of debris-rich ice with limestone resulted in their polishing with fine-grained material (clay to silt fraction) and formation of striae and crag-and-tail forms due to the impact of the sandy-gravelly fraction (Glasser and Bennett 2004).

During the phase of low SWP, an effective deposition of moraine material practically did not occur. The movement was concentrated in the sliding zone beneath of moving ice, from a few to a dozen or so centimetres thick, and the abrasion of the substrate by coarse grained clasts embedded in the ice bottom occurred, according to the ploughing model (Tulaczyk et al. 2001).

\section{High SWP}

In the studied sites, the free drainage of subglacial water was impeded by the Upper Jurassic limestones and marls of the Zalesie structure, the frozen bed, continuous layers of fine-grained sediments within the Wapienno Formation as well as layers of diamicton. They formed low-permeability barriers that contributed to the local SWP. In such zones, 

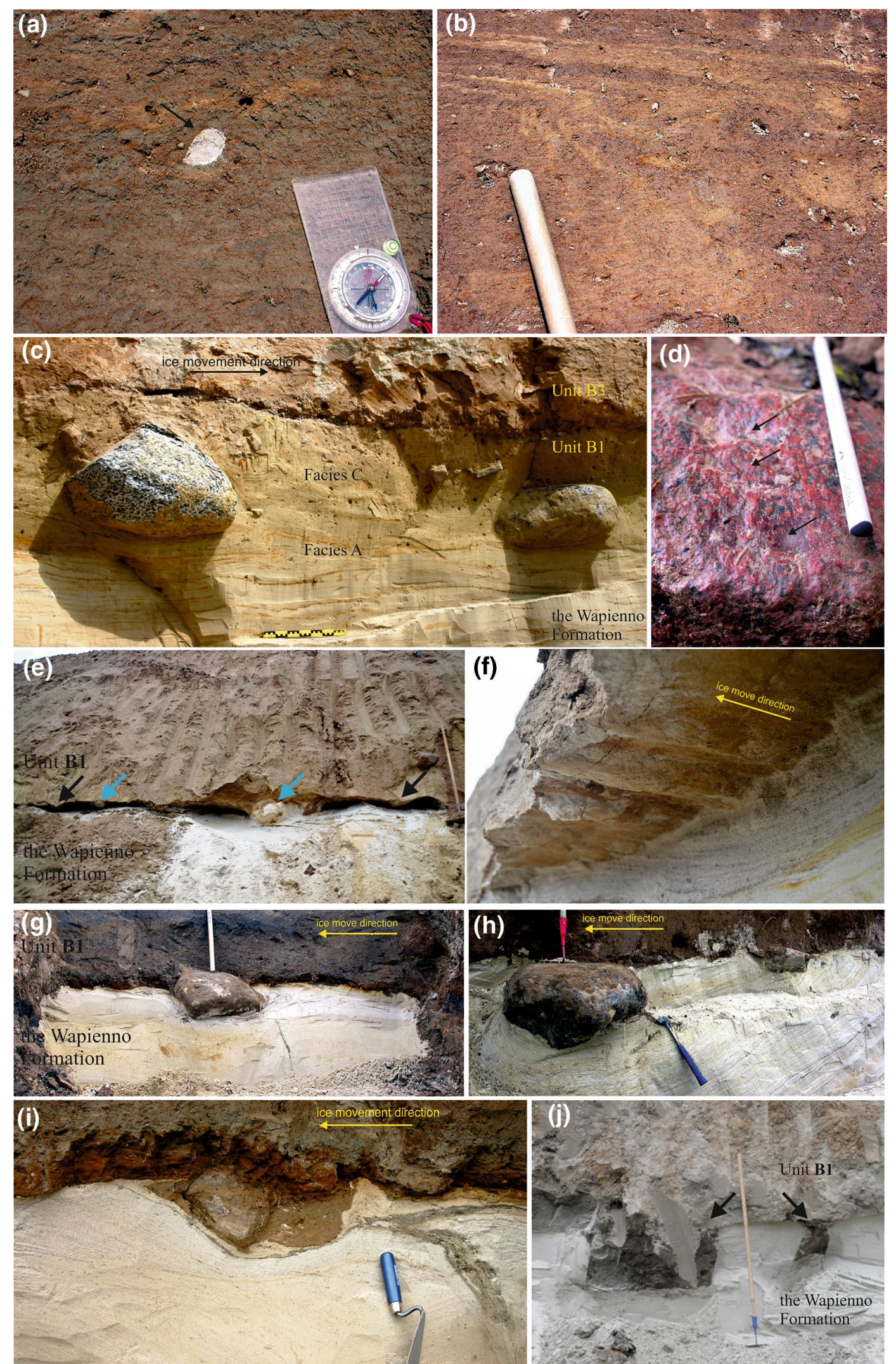
4Fig. 10 Western part of the Wapienno site: a overconsolidated diamicton of facies $\mathrm{C}$ with undeformed soft clast (black arrow); b massive to laminated structure of facies $\mathrm{C}$ diamicton; $\mathbf{c}$ Boulder pavement in the Barcin site at the interface between facies $A$ and C. Notice upward increasing of tectonic lamination in facies A; $\mathbf{d}$ crescentic gouges (black arrows) at the upper surface of boulder at the bottom of unit B1, the Młodocin site; western part of the Wapienno site: $\mathbf{e}$ boulder pavement (blue arrows) and diamicton keels (black arrows). Ice movement towards observers; $\mathbf{f}$ small diamicton keels at the bottom site of the unit B1; $\mathbf{g}$ a boulder with ploughing structures; $\mathbf{h}$ boulder pavement with ploughing structures, the Młodocin site; i boulder with ploughing structure and diamicton infilling small cavity behind, eastern part of the Wapienno site; $\mathbf{j}$ The eastern Wapienno quarry. N-type subglacial channels cutting sand sediments of the Wapienno Formation infilled with massive clay-rich diamcton of subfacies $\mathrm{C}$ of the unit B1

deformations of freshly deposited diamicton and substrate sediments were developing on at the ice-bed contact. The horizontal lamination appearing in deformation zones can be interpreted as a result of deformation caused by shear stress and formation of tectonic lamination (Boulton et al. 2001; Linden et al. 2008; Narloch et al. 2013). Depending on pore pressure, the moraine material could be deposited as layers of compact diamicton thanks to fast consolidation during effective dreinage (origin of subfacies $\mathrm{B}_{1}$ ) or become mixed with sandy sediments of the substrate in more liquid conditions (origin of subfacies $\mathrm{B}_{2}$; Fig. 7). Such a watersaturated sediment decreased the effective friction of the ice against the substrate (Phillips et al. 2018). Thus, the ice movement accelerated. The deformations were disappearing towards the bottom due to the gradual decrease of shear stress induced by the pressure of the moving ice sheet (Evans et al. 2006). The gradual downward transition from continuous to brittle deformation indicates the gradual decrease of plastic properties of the deformed sediments and dominance of deformations of the brittle type (origin of facies A; Fig. 7). On a hard substrate with a low permeability (Upper Jurassic limestones in this case), excess water could not be drained through substrate drainage or the development of clastic dykes. This forced the high-pressure flow of highly water-saturated moraine material. The high-pressure sediment flow created sinuous erosional forms such as p-forms and s-forms (Shaw 1988; Munro-Stasiuk et al. 2005).

A further increase of SWP reached the critical level, i.e., $95 \%$ of the pressure of static ice. At this level, the ice was decoupled from the substrate and the friction fell almost to zero. The loss of contact with the substrate and appearance of a widely distributed layer of water or highly liqiufied mixture of water and fine material (subfacies $\mathrm{B}_{1}$, Fig. 8f) at the ice-bed contact caused the acceleration of the ice movement. Locally, in the eastern part of the Wapienno quarry, N-type subglacial channels were found immediately below subfacies $\mathrm{C}$ of B1 till (Fig. 10j). They suggest that, during the buildup of high SWP, water accumulated locally at the ice-bed contact and then, in conditions of critical pressure levels, it was released through a system of channels dissecting the soft substrate. The characteristic steep walls of $\mathrm{N}$-type channels incised in the sands of the Wapienno Formation and the lack of deformation of sands at the contact with the diamicton filling them suggest that the dissected soft substrate was in a frozen state. This suggests that basal ice locally rested on permafrost patches. Evidence for the existence of permafrost in the soft substrate beneath basal ice in the Polish Lowlands was recently presented by Tylmann et al. (2013) and Narloch et al. (2013).

\section{Clastic dykes}

The overpressurising of sediments resulted in their hydraulic fracture and injections of clastic material into them and development of clastic dykes (Jolly and Lonergan 2002; Le Heron and Etienne 2005; van der Meer et al. 2009). Their development was also fostered by the shear stress forming below the moving ice sheet, because tension fractures were forming locally due to the stress. Clastic dykes that develop under an extensional regime also testify to the occurrence of local increase in pore pressure (Boulton and Caban 1995; McCarroll and Rijsdijk 2003; Denis et al. 2009). Pressure gradients were orientated through the low conductivity deformation till into the highly permeable fluvial sands. The filling of large dykes with different types of material indicate multiphase development. The fractures were renewed during subsequent stages of pressure gradient increase (van der Meer et al. 1999; Rijsdijk et al. 1999; Le Heron and Etienne 2005). In earlier phases, the fractures were mainly filled with fine-grained fractions that currently occur in the outer part of large dykes (Fig. 9b). At a later stage, mainly fine sand and sandy diamicton intruded. The subhorizontal disappearance of smaller forms within the sands of the Wapienno Formation indicates that there was a barrier impeding their downward development (Fig. 9c). This barrier was presumably formed by permafrost still present in the deeper (at the depth of a few metres) parts of substrate sediments. The presence of clay aureoles around them suggests that at the time of their development, the host sediment was not frozen immediately beneath the ice to the depth of 1-2 $\mathrm{m}$. The migration of clay particles beyond the outer walls of hydrofractures additionally reduced the permeability of sandy sediments (Phillips et al. 2013). The dykes formed mainly in areas, where the drainage was obstructed by the developing layers of deformation till, patches of permafrost under the ice bottom and/or clay-silt lenses present in the sandy sediments of the Wapienno Formation. The formation of clastic dykes could have regulated the SWP and prevented the exceeding of critical levels leading to the decoupling of the ice sheet bottom from the substrate (van der Meer et al. 2009; Phillips et al. 2013). This indicates that the SWP increase 
was local and temporary, typical of the mosaic model. What is also important, the presence of clastic dykes is regarded as a diagnostic for marginal zones developing within a few to a dozen or so kilometres from the front of the ice sheet (Linden et al. 2008). This allows us to conclude that the development of the structures and sediments formed during the development of facies A and B occurred mainly in the marginal zone of the advancing ice sheet (Fig. 11a).

\section{Facies C}

The diamicton of facies $\mathrm{C}$ has a massive structure with the recorded stress system proving a strong horizontal stress (simple shear, Fig. 7). At the same time, clear traces of displacement along shear planes, typical of traction till, are absent (Evans et al. 2006). The massive character of the till may suggest the continuous accretion of the released basal debris and its very weak deformation at the contact with the ice coupled with the substrate (cf., e.g., Spagnolo et al.
2016). The absence of distinct deformations and presence of preserved soft clasts (Fig. 10a) within the till of facies $\mathrm{C}$ is interpreted as a result of the fast consolidation of the till due to its dehydration. The $S_{1}$ values themselves cannot be regarded as diagnostic for a specific process of subglacial deposition (Bennett et al. 1999). Nonetheless, in the subglacial shearing zones, this parameter usually achieves higher values than those measured at the studied sites (Larsen and Piotrowski 2003). Till-fabric mesurements in all key sites (Fig. 5) Suggest ice-movement direction towards SE. It can corresponds with aa extensive end lobe about $200 \mathrm{~km}$ towards SE, visible in Fig. 1.
Fig. 11 Model of SIS transgression phases: a phase I-icemarginal zone, frozen forefield; b phase II-maximum of SIS transgression, unfrozen bed conditions. DS deformation spot
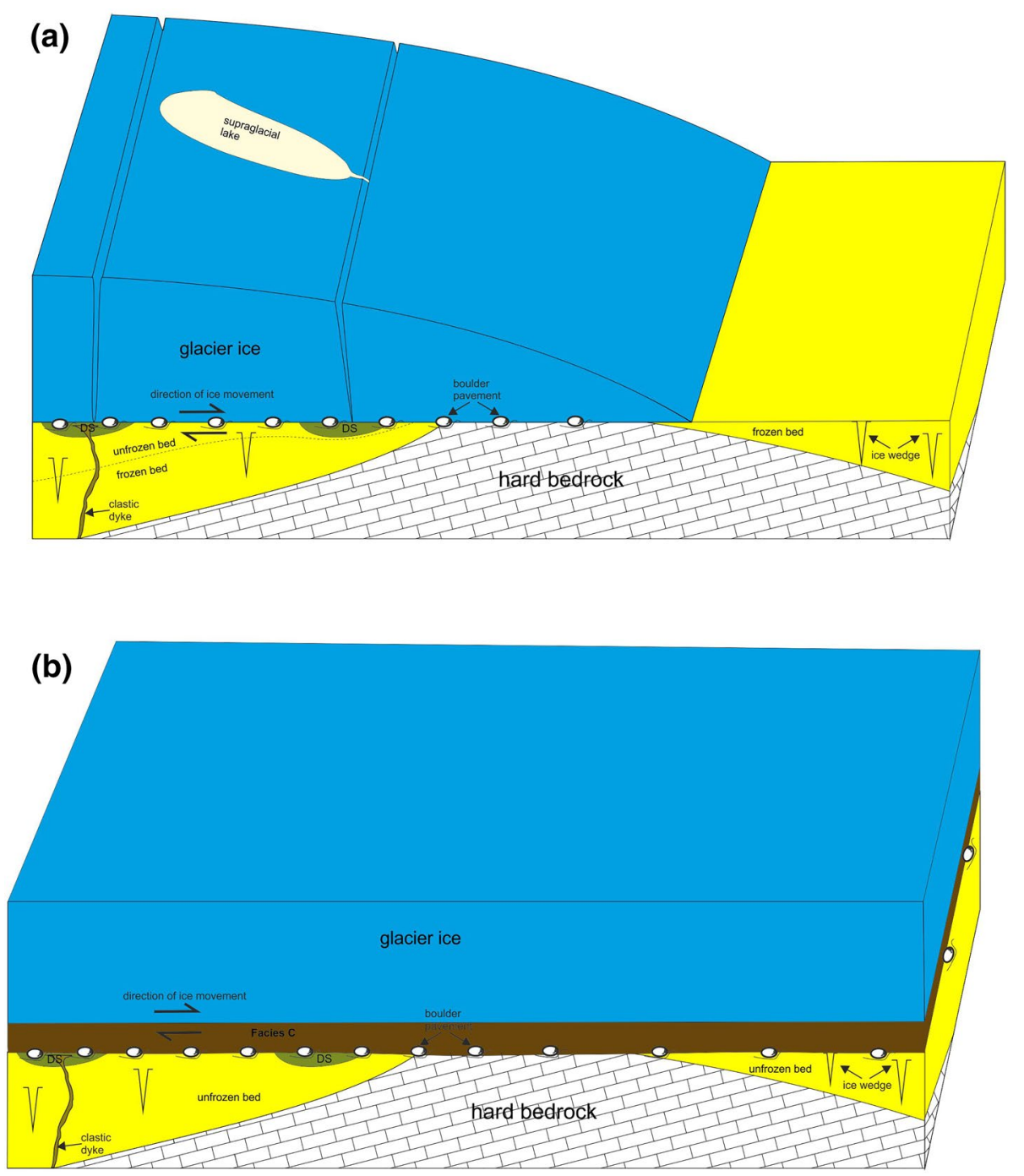


\section{Discussion}

\section{Influence of permafrost on ice dynamics}

One of the key factors for basal thermal conditions is the potential presence of permafrost beneath the ice sheet. The possible occurrence of permafrost in the study areas is confirmed by the presence of syngenetic ice-wedge casts in the sediments of the Wapienno Formation (Sokołowski and Czubla 2016) and presence of small channels of the $\mathrm{N}$ type, filled with diamicton in the top part of the Wapienno Formation sediments. Cutler et al. (2000) estimates that permafrost under the southern sector of the Laurentide Ice Sheet was melting during a period lasting from several hundred to even a few thousand years after the transgression of the ice sheet. The reduction of substrate permeability caused by the presence of permafrost beneath the ice sheet was also found by Salamon (2016) who believed that it was one of the main factors causing SWP increase under the ice sheet. Presumably in the initial stage of its transgression, the SIS advanced onto a frozen substrate and only its upper layer was melting. The melting occurred mainly as a result of the release of friction heating during the movement of the ice across the substrate. The depth of the ploughing marks, reaching $0.6-0.8 \mathrm{~m}$, is proportionately smaller in relation to the ploughing clasts than what the model presented by Tulaczyk et al. (2001) would suggest. This can be interpreted as an effect of the impact of the frozen substrate that reduced the thickness of the zone susceptible to deformations resulting from the ploughing process. In the initial phase of the SIS transgression, the presence of permafrost in the marginal zone of the ice sheet could have led (due to the reduced substrate permeability) to high SWP and increased basal sliding. In a later stage of the SIS transgression, the role of permafrost seems to have been smaller. This is suggested by several elements such as the vertically oriented clastic dykes and local ductile deformation of the Wapienno Formation sands. The relatively quick disappearance of permafrost could have been caused by the frictional heat released during basal sliding and the inflow of supraglacial water to the subglacial zone. The heat flux from the substrate could have also played a role. The depth and range of facies A in the zones of substrate sediment deformation show that, in a later phase of transgression, permafrost was melting and its role in keeping SWP at a high level was decreasing. The subsequent phase of transgression was developing in conditions of warm-based ice with the developing sediment deformation zones and clastic dykes.

\section{Role of substratum lithology and morphology}

The factors that played a significant role in controlling SWP included the lithology of the substrate and relief of the outcrops of Upper Jurassic limestones. The outcrops of low-permeability Mesozoic sediments in direct contact with the ice sheet were about 6-7 km long and 100-700 m wide (Sokołowski 2007). They were positioned at an oblique angle (WNW-ESE) in relation to the measured direction of ice movement (W-E). They could have constituted a local barrier obstructing the flow of subglacial water, contributing to its increased pressure and, consequently, accelerated ice movement. On the other hand, they probably were not the kind of barrier to the movement of ice as that posed by bedrock bump sticky spots beneath Ice Stream D from the Ross ice streams in West Antarctica (Joughin et al. 2004), because at the time of the SIS transgression, the limestones were practically totally covered by the sands of the Wapienno Formation. This enabled a local increase of SWP up to the level resulting in the detachment of ice from the substrate. Also the deposition of the diamicton (low-permeability layer) in the deformation zones could have locally increased the SWP and the vertical pressure gradient leading to the development of hydrofractures that were filled by overpressured liquefied sediment (clastic dykes).

\section{Model of subglacial processes}

A question thus arises: what were the reasons for the formation of the mosaic pattern of zones of deformation and basal sliding without the deformation of the substrate? The models proposed by various authors assume that the development of deformations is variable in time and space, and the ice sheet movement through the pervasive deformation of sediment beneath the ice is limited and does not play a major role (Fischer and Clarke 1997; Piotrowski et al. 2001, 2004, 2006; Knight 2002). The distances between deformation zones found in continuous exposures at the Wapienno site indicated that they could have developed directly at the contact with the ice crevasses reaching the substrate and thus enabling the migration of meltwater into the ice-bed contact (Boulton et al. 2001; Hart et al. 2019; Fig. 11a). The presence of clastic dykes and channels of N-type indicates the occurrence of considerable amounts of water (in relation to the capacity of the substrate) under a high pressure resulting in hydrofractures and channeled flows. The movement of ice thus occurred mainly through basal sliding with plastic deformations restricted to the layer of highly hydrated sediment several centimetres thick (Spagnolo et al. 2016).

\section{Palaeo-ice stream occurrence}

The potential ice-stream type of ice movement during the SIS transgression is a significant issue to be examined. The movement of ice in an ice-stream occurs at the speed at least an order of magnitude higher than the surroundings (Engelhardt and Kamb 1998; Stokes et al. 2007). The formation of ice-streams is favoured by an unconsolidated 
bottom with reduced permeability due to the formation of high subglacial water pressure and layer of overpressurised sediment that facilitates basal sliding (Tulaczyk et al. 2001; Piotrowski et al. 2004). The formation of Icestreams is also helped by the morphology of the substrate with elongated depressions such as river valleys or grabens that, in a way, force the concentration of ice flow (Sejrup et al. 2003; Bradwell et al. 2008; Salamon 2017). The occurrence of ice streams in the southern sector of the SIS during the Last Glaciation has been found in Poland, Germany and Denmark (Jørgensen and Piotrowski 2003; Przybylski 2008; Wysota et al. 2009; Salamon 2017; Gehrmann and Harding 2018).

The Wapienno Formation sediments, onto which SIS advanced, filled a latitudinally oriented river valley. The valley was drained in the western direction, which means that the longitudinal profile of the valley was slightly inclined in the opposite direction in relation to the direction of the advancing ice sheet. The existing valley could have been used by the transgressing ice masses in the same way as it occurred during the Elsterian Glaciation in the valley of the upper Odra river in SW Poland (Salamon 2017).

Linear elements both on a hard and soft substrate (glacial striae, lineations, till keels), ploughing structures as well as the mosaic pattern of substrate sediment deformation zones are regarded as diagnostics for zones of fast ice movement (Clark and Hansel 1989; Stokes and Clark 2002; Jørgensen and Piotrowski 2003; Piotrowski et al. 2004, 2006; Jennings 2006; Kjær et al. 2006; Stokes et al. 2007; Bradwell et al. 2008; O'Cofaigh et al. 2013; Spagnolo et al. 2016). The possibility of the occurrence of high SWP was proven above, particularly in the initial phase of SIS transgression. When the size of erosion structures found at the Wapienno site is compared with similar structures from other areas with a hard bedrock, it is evident that the Wapienno structures are clearly smaller (Munro-Stasiuk et al. 2005). If we assume that their size reflects the duration of erosion processes and the thickness of the ice, we can conclude that the hypothetical ice stream functioned for a short period and presumably was not very thick (not more than $250 \mathrm{~m}$ ) (Salamon 2015). The perpendicular movement direction (W-E) in relation to the position of the main SIS ice mass can be explained with the activity of various ice streams in the forefield of the ice sheet. Such a situation occurred during the Last Glaciation in Denmark (2011) and NE Germany (Gehrmann and Harding 2018). Also palaeo-ice streams in the Wielkopolska region (western Poland) during the Leszno Phase (older) and Poznan Phase (younger) of the Weichselian Glaciation flowed in different directions (Przybylski 2008; Wysota et al. 2009; Roman 2019). What is important, the ice-stream type of ice movement and the directions towards the East during the Elsterian advance of the SIS are suggested for SW Poland in the Odra valley (Salamon 2017).
The different directions of ice movement and different facies development of the till in unit B1 reflects two development phases of SIS transgression (Fig. 11).

\section{Phase I}

A fast movement of ice from the west predominated during this phase. The thickness of the ice did not exceed $250 \mathrm{~m}$. The speed of ice movement varied and was determined by the seasonal delivery of meltwater into the ice-bed contact. The ice movement presumably had an.

lobe-shaped ice margincharacter (Roman 2019). The SIS advanced on an area with a developed continuous permafrost, which, in the initial transgression phase, contributed to high levels of SWP. The ice-bed contact had a mosaic character. Zones of higher SWP were developing mainly in places of supraglacial water infiltration through a system of fractures in the ice. Diamicton was deposited there and then underwent deformations along with the lower lying sands of the Wapienno Formation. Outside the deformation zones, basal sliding predominated, focused in a thin layer of highly water-saturated sediments without a lasting deposition of the moraine material (subfacies $B_{1}$ ). The stress of the ice sheet on the substrate was borne mainly by the boulder pavement ploughing through the sediments, along with the clay keels developing behind them. After crossing the boundary level of shear stress, the boulders from the bottom of the ice sheet were released and lodged in the substrate sediments. The further movement of the ice occurred over the upper surface of the lodged boulders, which is manifested in their flatted surfaces with polishing marks and striae. With low SWP levels, abrasion predominated and linear structures were developing on the hard substrate. When the pressure increased, the ice was decoupled from the hard substrate, the pressurised liquefied sediment flowed, and structures of the p-form and s-form type developed.

\section{Phase II}

During this phase, the ice movement was slower and did not have a stream character. Its direction also changed to SE. It was the main phase of transgression, during which the SIS reached its maximum range in the territory of Poland. The deposition of the main part of the diamicton occurred then. Its massive structure, preserved soft clasts and system of fractures of the Riedl type indicate a smaller role of shear stress and deposition mainly as a result of the lodgement process (lower part of facies $\mathrm{C}$ ). The highest part of facies $\mathrm{C}$ was deposited in stagnant ice conditions in a melt-out process. 


\section{Conclusions}

Summing up, the following conclusions can be stated:

- the diverse set of erosion, deformation and depositional structures beneath the till in unit B1 indicates the mosaic model of deforming and stable spots;

- the SIS transgressed onto permafrost that, in the initial phase, played a fundamental role in maintaining a high SWP;

- high SWP was locally mitigated by the development of hydrofractures (clastic dykes) and N-type channels;

- the presence of low-permeability hard bedrock (Upper Jurassic limestones and marls) was conducive to the continued high levels of SWP;

- in the initial phase of SIS transgression, the movement of ice had a latitudinal direction and used the previously existing river valley; it presumably had the form of an ice stream;

- the ice stream character of ice movement disappeared during the main phase of SIS transgression.

The presence of the ice stream during the transgression of the SIS in north-central Poland during MIS 6a and its further movement towards the east are issues that require further investigation. New investigation results from other study sites in central Poland should shed some light on this problem and, more broadly, on the dynamics of the southern sector of the SIS during MIS6a.

Acknowledgements We would like to thank Olaf Juschus and an anonymous Journal reviewer for their constructive and helpful comments. Many thanks are addressed to Editor-in-Chief, Wolf-Christian Dullo, for patience and help during preparation of the manuscript.

Open Access This article is licensed under a Creative Commons Attribution 4.0 International License, which permits use, sharing, adaptation, distribution and reproduction in any medium or format, as long as you give appropriate credit to the original author(s) and the source, provide a link to the Creative Commons licence, and indicate if changes were made. The images or other third party material in this article are included in the article's Creative Commons licence, unless indicated otherwise in a credit line to the material. If material is not included in the article's Creative Commons licence and your intended use is not permitted by statutory regulation or exceeds the permitted use, you will need to obtain permission directly from the copyright holder. To view a copy of this licence, visit http://creativecommons.org/licenses/by/4.0/.

\section{References}

Benn DI, Evans DJA (2010) Glaciers and Glaciation, 2nd edn. Arnold Publication, London

Bennett MM, Glasser NF (2011) Glacial geology: ice sheets and landforms. John Wiley and Sons, New Jersey, pp 1-364
Bennett MR, Waller RI, Glasser NF, Hambrey MJ, Huddart D (1999) Glacigenic clast fabric: genetic fingerprint or wishful thinking? J Quat Sci 14:125-135

Boulton GS (1986) A paradigm shift in glaciology. Nature 322:18

Boulton GS, Caban PE (1995) Groundwater flow beneath ice sheets: part II-its impact on glacier tectonic structures and moraine formation. Quat Sci Rev 14:563-587

Boulton GS, Hindmarsh RCA (1987) Sediment deformation beneath glaciers: rheology and geological consequences. J Geophys Res 92:9059-9082

Boulton GS, Dobbie KE, Zatsepin S (2001) Sediment deformation beneath glaciers and its coupling to the subglacial hydraulic system. Quat Int 86:3-28

Bradwell T, Stoker M, Krabbendam M (2008) Megagrooves and streamlined bedrock in NW Scotland: the role of ice streams in landscape evolution. Geomorphology 97:135-156

Cepek AG (1995) Stratigraphie und Inlandeisbewegungen im Pleistozän an der Struktur Rüdersdorf bei Berlin. In: Schroeder JH (ed) Fortschritte in der Geologie von Rüdersdorf. Berliner geowissenschaftliche Abhandlungen, Reihe, pp 1103-1134

Clark PU, Hansel AK (1989) Clast ploughing, lodgement and glacier sliding over a soft glacier bed. Boreas 18:201-207

Clerc S, Buoncristiani JF, Guiraud M, Desaubliaux G, Portier E (2012) Depositional model in subglacial cavities, Killiney Bay, Ireland. Interactions between sedimentation, deformation and glacial dynamics. Quat Sci Rev 33:142-164

Cofaigh C, Stokes CR, Lian OB, Clark CD, Tulaczyk S (2013) Formation of mega-scale glacial lineations on the Dubawnt Lake Ice Stream bed: 2. Sedimentology and stratigraphy. Quat Sci Rev 77:210-227

Cutler PM, MacAyeal DR, Mickelson DM, Parizek BR, Colgan PM (2000) A numerical investigation of ice-lobe-permafrost interaction around the southern Laurentide ice sheet. J Glaciol 46:311-325

Dadlez R, Narkiewicz M, Stephenson RA, Visser MTM, Van Vees J-D (1995) Tectonic evolution of the Mid-Polish Trough, modelling implications and significance for central European geology. Tectonophysics 252:179-195

Davis JC (1973) Statistics and data analysis in geology. Wiley and Sons, New York, pp 1-550

Dembowska J (1957) Z badan geologicznych w 1957 r. w obrębie antyklinorium kujawsko-pomorskiego. Kwartalnik Geologiczny 3:186-195

Denis M, Buoncristiani JF, Guiraud M (2009) Fluid-pressure controlled soft-bed deformation sequence beneath the surging Breiðamerkurjökull (Iceland, Little Ice Age). Sedim Geol 221:71-86

Ehlers J, Gibbard P (eds) (2004) Quaternary glaciations-extent and chronology. Vol. 1 Europe. Elsevier, Amsterdam, pp 135-146

Eissmann L (2002) Quaternary geology of eastern Germany (Saxony, Saxon-Anhalt, South Brandenburg, Thüringia), type area of the Elsterian and Saalian Stages in Europe. Quat Sci Rev 21:1275-1346

Engelhardt H, Kamb B (1998) Basal sliding of Ice Stream B, West Antarctica. J Glaciol 44:223-230

Evans IS (2007) Glacial landforms, erosional features I Major Scale Forms. In: Elias SA (ed) Encyclopedia of Quaternary Science. Oxford, Elsevier, pp 838-852. https://doi.org/10.1016/B0-44452747-8/00098-3

Evans DJA, Phillips ER, Hiemstra JF, Auton CA (2006) Subglacial till: formation, sedimentary characteristics and classification. Earth Sci Rev 78:115-176

Fischer U, Clarke GKC (1997) Stick-slip sliding behavior at the base of a glacier. Ann Glaciol 24:390-396

Fischer UH, Clarke GK, Blatter H (1999) Evidence for temporally "sticky spots" at the base of Trapridge glacier, Yukon Territory, Canada. J Glaciol 45:352-360 
Gehrmann A, Harding C (2018) Geomorphological mapping and spatial analyses of an upper Weichselian Glacitectonic complex based on LiDAR Data, Jasmund Peninsula (NE Rügen), Germany. Geosciences 8:1-24

Glasser NF, Bennett MR (2004) Glacial erosional landforms: origins and significance for palaeoglaciology. Progr Phys Geogr 28:43-75

Gray JM (1982) Un-weathered, glaciated bedrock on an exposed lake bed in Wales. J Glaciol 28:483-497

Harper JT, Humphrey NF, Pfeffer WT, Lazar BT (2007) Two modes of accelerated glacier sliding related to water. Geophys Res Lett 34:L12503

Hart JK, Martinez K, Basford PJ, Clayton AI, Bragg GM, Ward T, Young DS (2019) Surface melt-driven seasonal behaviour (englacial and subglacial) from a soft-bedded temperate glacier recorded by in situ wireless probes. Earth Surf Proc Land 44:1769-1782

Houmark-Nielsen M (2011) Pleistocene glaciations in Denmark: a closer look at chronology, ice dynamics and landforms. Dev Quat Sci 15:47-58

Iverson NR (1991) Morphology of glacial striae: implications for abrasion of glacier beds and fault surfaces. GSA Bull 103:1308-16

Iverson NR (2010) Shear resistance and continuity of subglacial till: hydrology rules. J Glaciol 56:1104-1114

Iverson NR, Hooyer TS, Baker RW (1998) Ring-shear studies of till deformation: Coulomb-plastic behavior and distributed strain in glacier beds. J Glaciol 44:634-642

Jennings CE (2006) Terrestrial ice streams-a view from the lobe. Geomorphology 75:100-124

Jolly RJH, Lonergan L (2002) Mechanisms and controls on the formation of sand intrusions. J Geol Soc 159:605-617

Jørgensen F, Piotrowski JA (2003) Signature of the Baltic Ice Stream on Funen Island, Denmark during the Weichselian glaciation. Boreas 32:242-255

Joughin I, MacAyeal DR, Tulaczyk S (2004) Basal shear stress of the Ross ice streams from control method inversions. J Geophys Res 109:B09405

Kjær KH, Larsen E, van der Meer J, Ingólfsson Ó, Krüger J, Benediktsson ÍÖ, Knudsen CG, Schomacker A (2006) Subglacial decoupling at the sediment/bedrock interface: a new mechanism for rapid flowing ice. Quat Sci Rev 25:2704-2712

Knight J (2002) Glacial sedimentary evidence supporting stick-slip basal ice flow. Quat Sci Rev 12:975-983

Kondracki J (1998) Geografia Polski. In: Mezoregiony fizyczno-geograficzne Wydawnictwo Naukowe PWN, pp 1-340 (in Polish)

Le Heron DP, Etienne JL (2005) A complex subglacial clastic dyke swarm, Sólheimajokull, southern Iceland. Sedim Geol 181:25-37

Lesemann J-E, Aslop GI, Piotrowski JA (2010) Incremental subglacial meltwater sediment deposition and deformation associated with repeated ice-bed decoupling: a case study from the Island of Funen, Denmark. Quat Sci Rev 29:3212-3229

Linden M, Möller P, Adrielsson L (2008) Ribbed moraine formed by subglacial folding, thrust stacking and lee-side cavity infill. Boreas 37:102-131

Lindner L, Bogutsky A, Gozhik P, Marks L, Łanczont M, Wojtanowicz $\mathrm{J}$ (2006) Correlation of Pleistocene deposits in the area between the Baltic and Black Sea, Central Europe. Geol Quart 50:195-210

Marks L (2004) Pleistocene glacial limits in Poland. In: Ehlers J, Gibbard P (eds) Quaternary glaciations extent and chronology. Part I: Europe. Elsevier, Amsterdam, pp 295-300

Marks L, Karabanov A, Nitychoruk J, Bahdasarau M, Krzywicki T, Majecka A, Pochocka-Szwarc K, Rychel J, Woronko B, Zbucki Ł, Hradunova A, Hrychanik M, Mamchyk S, Rylova T, Nowacki Ł, Pielach M (2018) Revised limit of the Saalian ice sheet in central Europe. Quat Int 478:59-74

McCarroll D, Rijsdijk KF (2003) Deformation styles as a key for interpreting glacial depositional environments. J Quat Sci 18:473-489
Minchew B, Simons M, Björnsson H, Pálsson F, Morlighem M, Seroussi H, Larour E, Hensley S (2016) Plastic bed beneath Hofsjökull Ice Cap, central Iceland, and the sensitivity of ice flow to surface meltwater flux. J Glaciol 62:147-158

Munro-Stasiuk MJ, Fisher TG, Nitzsche CR (2005) The origin of the western Lake Erie grooves, Ohio: implications for reconstructing the subglacial hydrology of the Great Lakes sector of the Laurentide Ice Sheet. Quat Sci Rev 24:2392-2409

Narloch W, Wysota W, Piotrowski JA (2013) Sedimentological record of subglacial conditions and ice sheet dynamics of the Vistula Ice Stream (north-central Poland) during the Last Glaciation. Sedim Geol 293:30-44

Phillips E, Everest J, Reeves H (2013) Micromorphological evidence for subglacial multiphase sedimentation and deformation during overpressurised fluid flow associated with hydrofracturing. Boreas 42:395-427

Phillips E, Evans DJA, van der Meer JJM, Lee JR (2018) Microscale evidence of liquefaction and its potential triggers during softbed deformation within subglacial traction tills. Quat Sci Rev 181:123-143

Piotrowski JA (2006) Groundwater under ice sheets and glaciers. In: Knight PG (ed) Glacier science and environmental change. Blackwell Publishing, Oxford, pp 50-60

Piotrowski JA, Michelson DM, Tulaczyk S, Krzyszowski D, Junge FW (2001) Were deforming bed beneath past ice sheets really widespread? Quat Int 86:139-150

Piotrowski JA, Larsen NK, Junge FW (2004) Reflections on soft subglacial beds as a mosaic of deforming and stable spots. Quat Sci Rev 23:993-1000

Piotrowski JA, Larsen NK, Menzies J, Wysota W (2006) Formation of subglacial till under transient bed conditions: deposition, deformation, and basal decoupling under a Weichselian ice sheet lobe, central Poland. Sedimentology 53:83-106

Przybylski B (2008) Geomorphic traces of a Weichselian ice stream in the Wielkopolska Lowland, western Poland. Boreas 37:286-296

Ravier E, Buoncristiani JF (2018) Glaciohydrogeology. In: van der MenziesMeer JJJM (ed) Past glacial environments. Elsevier, Amsterdam, pp 431-466

Rea B (2007) Glacial landforms, erosional features I Micro to Macro Scale Forms. In: Elias SA (ed) Encyclopedia of Quaternary Science. Oxford, Elsevier, pp 853-864

Rijsdijk KF, Owen G, Warren WP, McCarroll D, van der Meer JJM (1999) Clastic dykes in over-consolidated tills:evidence for subglacial hydrofracturing at Killiney Bay, eastern Ireland. Sedim Geol 129:111-126

Roman M (2019) Ice-flow directions of the last Scandinavian Ice Sheet in central Poland. Quat Int 501:4-20

Różycki SZ (1980) Principles of stratigraphic subdivisions of Quaternary of Poland. Quat Stud Pol 2:99-106

Salamon T (2015) Development of the topography-controlled Upper Odra ice lobe (Scandinavian Ice Sheet) in the fore-mountain area of southern Poland during the Saalian glaciation. Quat Sci Rev 123:1-15

Salamon T (2016) Subglacial conditions and Scandinavian Ice Sheet dynamics at the coarse-grained substratum of the fore-mountain area of southern Poland. Quat Sci Rev 151:72-87

Salamon T (2017) Elsterian ice sheet dynamics in a topographically varied area (southern part of the Racibórz-Oświęcim Basin and its vicinity, southern Poland). Geol Quart 61:465-479

Schulz W (1967) Über glazigene Schrammen auf dem Untergrund und sichelförmige Marken auf Geschieben in Norddeutschland. Geogr Ber 43:125-142

Sejrup HP, Larsen E, Haflidason H, Berstad IM, Hjelstuen BO, Jonsdottir HE, King EL, Landvik J, Longva O, Nygard A, Ottesen D, Raunholm S, Rise L, Stalsberg K (2003) Configuration, 
history and impact of the Norwegian Channel Ice Stream. Boreas 32:18-36

Shaw J (1988) Subglacial erosional marks, Wilton Creek, Ontario. Can J Earth Sci 25:1256-1267

Sokołowski RJ (2004) Litostratygrafia i procesy depozycji osadów glacigenicznych zlodowacenia wisły w kamieniołomie Wapienno k/Inowrocławia. In: Wysota W (ed) Terenowe warsztaty sedymentologiczne, Gliny morenowe: typy genetyczne i środowiska depozycji”. Wydawnictwo UMK, Tourn, pp 18-28

Sokołowski RJ (2007) Stratygrafia i sedymentologia osadów plejstocenu w kamieniołomie "Wapienno", NE Wielkopolska. Manuscript of the PhD thesis, Nicolaus Copernicus University, Torun.

Sokołowski RJ, Czubla P (2016) Sequence of Pleistocene deposits in the Wapienno quarry, north-central Poland. In: Sokołowski RJ, Moskalewicz D (eds) Quaternary geology of north-central Poland: from the Baltic coast to the LGM limit. University of Gdańsk, Gdańsk, pp 69-84

Spagnolo M, Clark CD, Ely JC, Stokes CR, Anderson JB, Andreassen K, Graham AGS, King EC (2014) Size, shape and spatial arrangement of mega-scale glacial lineations from a large and diverse dataset. Earth Surf Proc Land 39:1432-1448

Spagnolo M, Phillips E, Piotrowski JA, Rea BR, Clark CD, Stokes CR, Carr SJ, Ely JC, Ribolini A, Wysota W, Szuman I (2016) Ice stream motion facilitated by a shallow-deforming and accreting bed. Nat Commun 7:10723

Stokes CR, Clark CD (1999) Geomorphological criteria for identifying Pleistocene ice streams. Ann Glaciol 28:67-74

Stokes CR, Clark CD (2001) Palaeo-ice streams. Quat Sci Rev 20:1437-1457

Stokes CR, Clark CD (2002) Are long subglacial bedforms indicative of fast ice flow? Boreas 31:239-249

Stokes CR, Clark CD, Lian OB, Tulaczyk S (2007) Ice stream sticky spots: a review of their identification and influence beneath contemporary and palaeo-ice streams. Earth-Sci Rev 81:217-249

Svendsen JI, Alexanderson H, Astakhov VI, Demidov I, Dowdeswell JA, Funder S, Gataullin V, Henriksen M, Hjort C, HoumarkNielsen M, Hubberteb HW, Ingolfsson O, Jakobsson M, Kjaer KH, Larsen E, Lokrantz H, Lunkka J-P, Lysa A, Mangerud J,
Matioushkov A, Murray A, Moller P, Niessen F, Nikolskaya O, Polyak L, Saarnisto M, Siegert C, Siegert MJ, Spielhagen RF, Stein R (2004) Late quaternary ice sheet history of Northern Eurasia. Quat Sci Rev 23:1229-1271

Thomason JF, Iverson NR (2008) A laboratory study of particle ploughing and pore-pressure feedback: a velocity-weakening mechanism for soft glacier beds. J Glaciol 54:169-181

Torell O (1875) Über eine gemeinschaftlich mit den Herren Berendt und Orth nach Rüderesdorfer Kalkbergen unternommenen Ausflug. In: Zeitschrift der Deutschen geologischen Gesellschaft 27:961-962

Tulaczyk S, Scherer RP, Clark CD (2001) A ploughing model for the origin of weak tills beneath ice streams: a qualitative treatment. Quat Int 86:59-70

Tylmann K, Piotrowski JA, Wysota W (2013) The ice/bed interface mosaic: deforming spots intervening with stable areas under the fringe of the Scandinavian Ice Sheet at Sampława, Poland. Boreas 42:428-441

van der Meer JJM, Kjær KH, Krüger J (1999) Subglacial waterescape structures and till structures, Slettjökull, Iceland. J Quat Sci 14:191-205

van der Meer JJM, Kjær KH, Krüger J, Rabassa J, Kilfeather AA (2009) Under pressure: clastic dykes in glacial settings. Quat Sci Rev 28:708-720

Van der Wateren FM, Kluving SJ, Bartek LR (2000) Kinematic indicator of subglacial shearing. Geol Soc Spec Publ 176:259-278

Wahnschaffe F (1893) Über zwei neue Fundorte von Gletscherschrammen auf anstehendem Gestein im norddeutschen Glazialgebiete. Zeitschrift der Deutschen geologischen Gesellschaft 44:705-709

Wahnschaffe F (1909) Die Oberflächengestaltung des norddeutschen Flaschlandes, pp 1-212, Stuttgart

Waller R, Murton JB, Kristensen L (2012) Glacier-permafrost interactions: processes, products and glaciological implications. Sedim Geol 255(256): 1-28

Wysota W, Molewski P, Sokołowski RJ (2009) Record of the Vistula ice lobe advances in the LateWeichselian glacial sequence in north-central Poland. Quat Int 207:26-41 